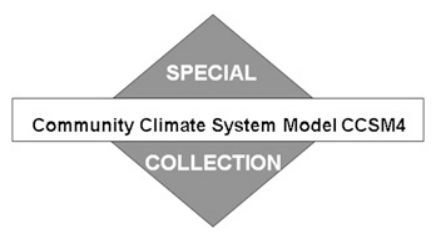

\title{
The Southern Ocean and Its Climate in CCSM4
}

\author{
Wilbert Weijer, ${ }^{*},+$ Bernadette M. Sloyan, ${ }^{\#, @ ~ M A t h e w ~ E . ~ M A l t r u d, ~}{ }^{*}$ Nicole Jeffery, ${ }^{*}$ \\ MatThew W. Hecht, ${ }^{*}$ Corinne A. HARtin, ${ }^{\&}$ ERIK VAN Sebille, ${ }^{\&} @ @$ IlanA WAineR,** \\ AND LAURA LANDRUM ${ }^{++}$ \\ * Los Alamos National Laboratory, Los Alamos, New Mexico \\ ${ }^{+}$The New Mexico Consortium, Los Alamos, New Mexico \\ \# Centre for Australian Weather and Climate Research, CSIRO, Hobart, Tasmania, Australia \\ @ CSIRO Wealth from Oceans National Research Flagship, Hobart, Tasmania, Australia \\ ${ }^{\&}$ Rosenstiel School of Marine and Atmospheric Science, University of Miami, Miami, Florida \\ ** Department of Physical Oceanography, University of São Paulo, São Paulo, Brazil \\ ${ }^{++}$National Center for Atmospheric Research, ${ }^{\#}$ Boulder, Colorado
}

(Manuscript received 3 June 2011, in final form 22 September 2011)

\begin{abstract}
The new Community Climate System Model, version 4 (CCSM4), provides a powerful tool to understand and predict the earth's climate system. Several aspects of the Southern Ocean in the CCSM4 are explored, including the surface climatology and interannual variability, simulation of key climate water masses (Antarctic Bottom Water, Subantarctic Mode Water, and Antarctic Intermediate Water), the transport and structure of the Antarctic Circumpolar Current, and interbasin exchange via the Agulhas and Tasman leakages and at the Brazil-Malvinas Confluence. It is found that the CCSM4 has varying degrees of accuracy in the simulation of the climate of the Southern Ocean when compared with observations. This study has identified aspects of the model that warrant further analysis that will result in a more comprehensive understanding of oceanatmosphere-ice dynamics and interactions that control the earth's climate and its variability.
\end{abstract}

\section{Introduction}

The Southern Ocean is a region of extremes: it is exposed to the most severe winds on the earth (Wunsch 1998), the largest ice shelves (Scambos et al. 2007), and the most extensive seasonal sea ice cover (Thomas and Dieckmann 2003). These interactions among the atmosphere, ocean, and cryosphere greatly influence the dynamics of the entire climate system through the formation of water masses and the sequestration of heat, freshwater, carbon, and other properties (Rintoul et al. 2001). In addition, the Southern Ocean plays an important role in the global distribution of these agents, as its unique geography

\footnotetext{
\#\# The National Center for Atmospheric Research is sponsored by the National Science Foundation.

@@ Current affiliation: Climate Change Research Centre, University of New South Wales, Sydney, New South Wales, Australia.

Corresponding author address: Wilbert Weijer, CCS-2, MS B296, Los Alamos National Laboratory, Los Alamos, NM 87545.

E-mail: wilbert@lanl.gov
}

(Fig. 1a) allows for the exchange of water masses between the major ocean basins (Tchernia 1980; Rintoul et al. 2001; Tomczak and Godfrey 2003). Although the official definition limits the Southern Ocean to the area south of $60^{\circ} \mathrm{S}$, a more consistent oceanographic designation would include all Antarctic and Subantarctic waters south of the subtropical convergence (roughly at $40^{\circ} \mathrm{S}$ ). With this definition, the Southern Ocean occupies about $20 \%$ of the world's ocean area. This paper explores several key aspects of the Southern Ocean and its climate in the new Community Climate System Model, version 4 (CCSM4).

Three key climate water masses are formed in the Southern Ocean-Antarctic Bottom Water (AABW; $\left.\theta<2{ }^{\circ} \mathrm{C}, 34.1<S<34.6 \mathrm{psu}\right)$, Antarctic Intermediate Water (AAIW; $2^{\circ}<\theta<6^{\circ} \mathrm{C}, S<34.4 \mathrm{psu}$ ), and Subantarctic Mode Water (SAMW; $6^{\circ}<\theta<10^{\circ} \mathrm{C}, 34.7<$ $S<34.4 \mathrm{psu}$ ). These water masses play an important role in the global climate by sequestering carbon and other greenhouse gases, heat, and freshwater from the atmosphere to the middepth $(\approx 1000 \mathrm{~m})$ and abyssal ocean (Orsi et al. 1999; Sabine et al. 2004). AABW is the dominant water mass of the global abyssal ocean 


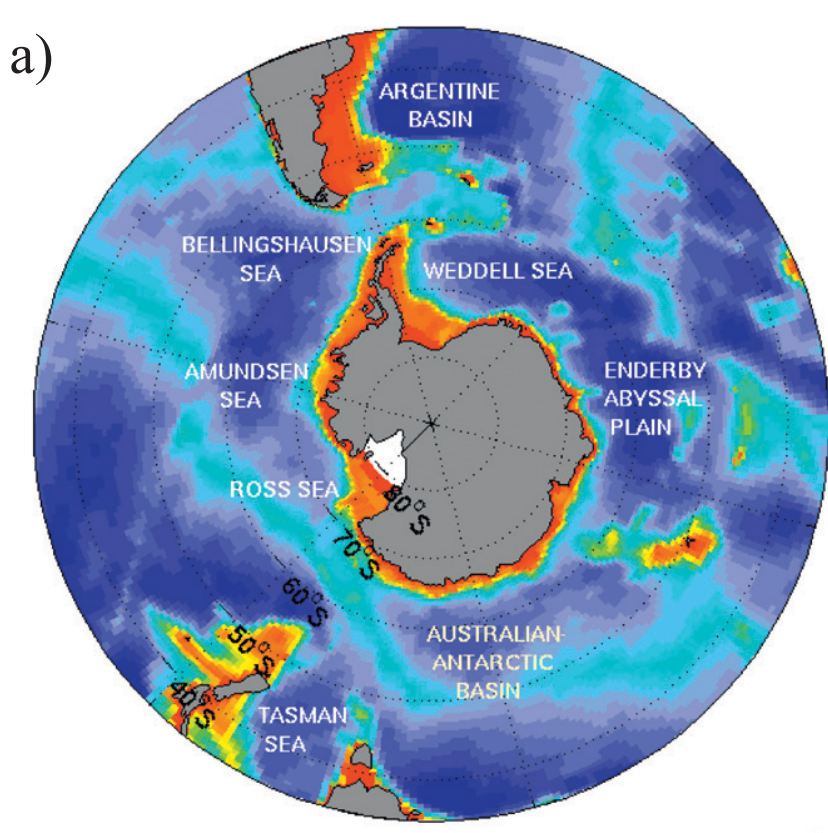

b)

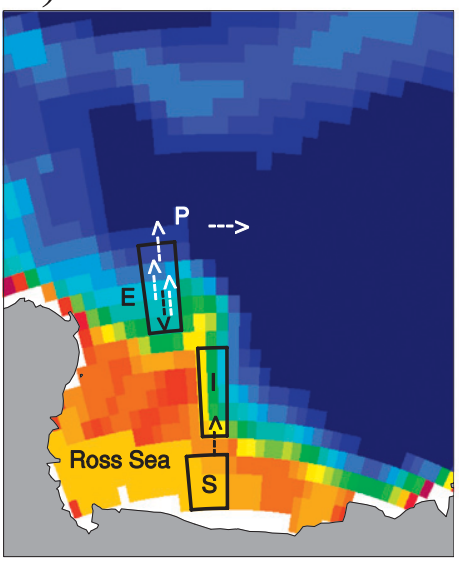

Depth In Meters

200300400500600700850100013001700200025003500

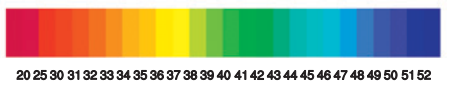

Vertical Level c)

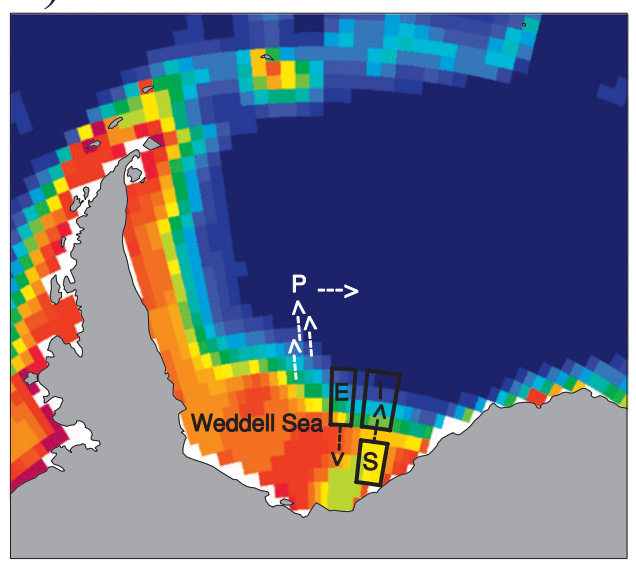

Depth In Meters

20030040045050055060070080090010001300170020002300270030003500

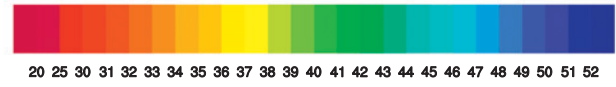

Vertical Level

FIG. 1. Model bathymetry in (a) the Southern Ocean and the (b) Ross and (c) Weddell Seas, with regions marked that are included in the overflow parameterization, as detailed in Briegleb et al. (2010) and Danabasoglu et al. (2012). The regions denoted by S, I, and E are those where the properties of source, interior, and entrainment waters are evaluated, respectively. Fluxes of source and entrainment waters through what would otherwise be solid sidewalls occur where arrows are drawn, and flow out at the product water sites, some of which are indicated with white arrows. Panels (b) and (c) are reprinted from Briegleb et al. (2010); we thank the authors and the National Center for Atmospheric Research for allowing this reuse.

(Johnson 2008). Its formation-in the Weddell Sea, Ross Sea, and along the Adélie Coast-is driven by brine rejection from seasonal sea ice formation and airsea heat loss in coastal polynyas. Entrainment processes increase the volume and modify the properties of the dense shelf water masses as they overflow off the Antarctic continental shelves into the abyssal ocean (Legg et al. 2009). AABW is transported to the global abyssal ocean in deep western boundary currents east of the Kerguelen Plateau (Fukamachi et al. 2010) and off the 
Antarctic Peninsula in the Weddell Sea (Gordon et al. 2001; Fahrbach et al. 2001).

AAIW and SAMW are found near and equatorward of the Antarctic Circumpolar Current (ACC). Increased anthropogenic carbon and transient tracer concentrations are associated with these water masses (Sabine et al. 2004; Fine et al. 2008; Hartin et al. 2011). SAMW and AAIW enter the subtropical gyre at the base of the thermocline and are important components of the upperocean nutrient cycle, impacting the efficiency of the global marine ecosystem (Sloyan and Rintoul 2001a; Sarmiento et al. 2004).

The Southern Ocean plays an important role as a conduit for the interbasin exchange of water masses and properties (Rintoul et al. 2001; Meredith et al. 2011). Most of this exchange is accomplished by the ACC, which is the strongest ocean current in the global ocean. Because of the lack of a closed continental boundary, it flows continuously around the Antarctic continent. Interactions across the subtropical convergence are essential for the exchange of water masses between the Subantarctic and subtropical zones of the Southern Hemisphere. One region where such exchange takes place is the energetic Brazil-Malvinas Confluence (BMC) - the region where the southward-flowing Brazil Current collides with the northward-flowing branch of the ACC: the Malvinas Current. The location of the BMC varies on time scales from a few days to years (e.g., Olson et al. 1988; Garzoli and Garraffo 1989; Wainer et al. 2000).

Other relevant westward interbasin exchanges take place just north of the ACC. Agulhas leakage (de Ruijter et al. 1999; Beal et al. 2011) and Tasman leakage (Rintoul and Sokolov 2001; Speich et al. 2002) are components of the Southern Hemisphere supergyre and combine to form the main routes to balance the outflow of North Atlantic Deep Water from the Atlantic (Gordon 1986, Gordon et al. 1992; Sloyan and Rintoul 2001a). Agulhas leakage occurs mostly through the intermittent shedding of Agulhas rings from the Agulhas retroflection (Byrne et al. 1995; Schouten et al. 2000). This process critically depends on the inertia of the Agulhas Current, and is therefore difficult to represent in relatively viscous, non-eddy-permitting models. Tasman leakage is identified as westward flow between Tasmania and the eastwardflowing ACC. Rintoul and Sokolov (2001) suggest that the variability in the strength of the Tasman leakage is linked to meridional shifts in the wind stress curl. Several modeling studies suggest that Agulhas leakage may affect the strength of the Atlantic overturning circulation (Weijer et al. 1999, 2002; Knorr and Lohmann 2003; van Sebille and van Leeuwen 2007; Marsh et al. 2007; Biastoch et al. 2008) as well as the heat content of the Atlantic Ocean (Lee et al. 2011); although direct observational support is still lacking, the proxy record is not inconsistent with these ideas (Berger and Wefer 1996; Peeters et al. 2004; Franzese et al. 2006).

Interannual variability of the Southern Ocean is strongly affected by internal climate modes-in particular the southern annular mode (SAM) and El Niño-Southern Oscillation (ENSO; e.g., Mo 2000). The SAM is a zonally symmetric mode of mostly atmospheric variability that is characterized by a meridional exchange of mass between Antarctica and a zonal ring around $45^{\circ} \mathrm{S}$ (e.g., Thompson and Wallace 2000; Hall and Visbeck 2002). A positive phase is associated with a strengthening and poleward shift of the westerly wind belt. The maximum of zonally averaged zonal wind stress can differ between 0.13 and $0.20 \mathrm{~N} \mathrm{~m}^{-2}$ between extreme phases of the SAM, and its location can shift between $48^{\circ}$ and $53^{\circ} \mathrm{S}$ (Visbeck 2009).

The impact of ENSO is mostly felt through atmospheric teleconnections (Turner 2004): a warm ENSO phase (El Niño) and its associated deep convection in the central equatorial Pacific generate a quasi-stationary Rossby wave train (e.g., Karoly 1989) that is known as the Pacific-South American (PSA) pattern (one of two PSA modes; e.g., Mo and Ghil 1987; Ghil and Mo 1991; Mo and Higgins 1998). It establishes a high-pressure area over the Amundsen-Bellingshausen Seas that promotes blocking events (Renwick 1998; Renwick and Revell 1999) and leads to positive temperature anomalies and a reduction in sea ice in this region (Kwok and Comiso 2002). A cold phase of ENSO (La Niña) has the opposite effect.

The SAM and ENSO signals are not fully independent, as positive phases of SAM occur more often during La Niña years, while negative phases are more prevalent during El Niños (Fogt et al. 2011).

This study evaluates the CCSM4 simulation for several key features of the Southern Ocean climate including important atmosphere-cryosphere-ocean interactions (section 3). Section 4 considers the climate model simulation of Southern Ocean water masses (AABW, SAMW, and $\mathrm{AAIW}$ ) and the seasonal cycle of the mixed layer depth and uptake of chlorofluorocarbons (CFC-11) by comparison with observations. Section 5 addresses the representation of key circulation features, like the export pathways of AABW, the transport and location of the ACC, the BMC, and the Agulhas and Tasman leakages. The summary and conclusions (section 6) close the paper.

\section{Datasets}

The analyses presented here focus on an ensemble of five twentieth-century (20C) integrations of the CCSM4, indicated by their case name extensions 005-009. A detailed 
a)

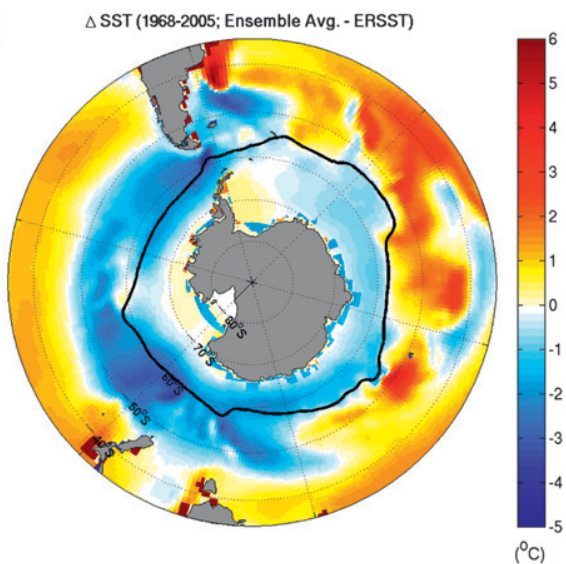

c)

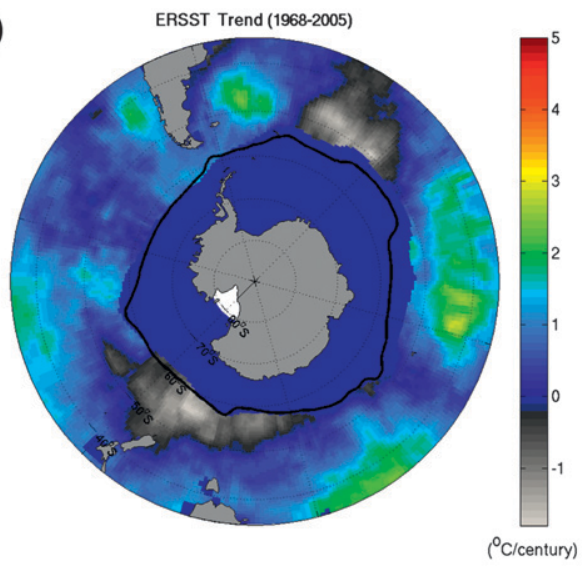

b)

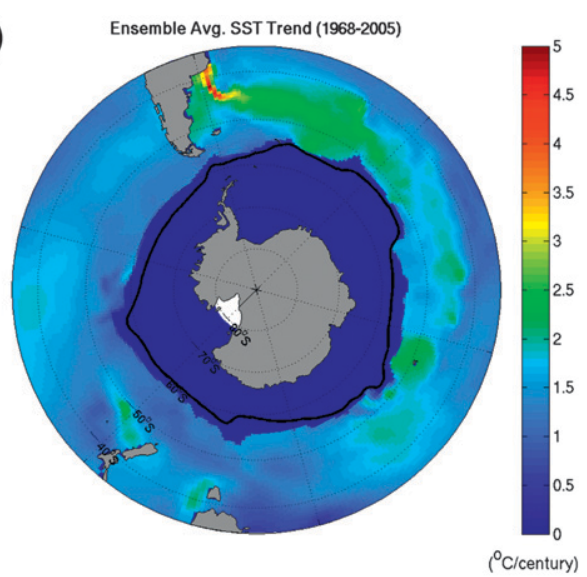

d)

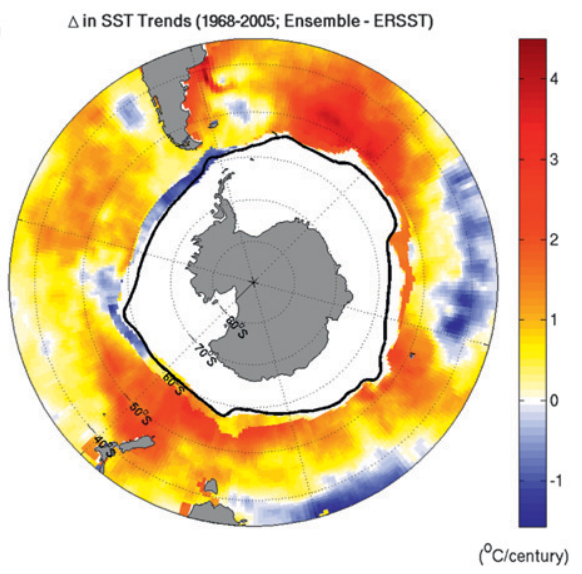

FIG. 2. (a) Difference between SST for the ensemble average over the 1968-2005 period and the ERSSTv3b analysis, (b) linear trends in SST for the ensemble average over the 1968-2005 period, (c) linear trends in ERSSTv3b analysis for the same period (Smith et al. 2008), and (d) difference between linear trends in SST for the ensemble average and the ERSSTv3b analysis. Only trends larger than their respective $t$ ratios are shown. Also shown is the CCSM4 ensemble average maximum sea ice extent over the same period (black contours).

description of the model configuration and the simulations can be found in Gent et al. (2011) and Danabasoglu et al. (2012). The 20C simulations were run from 1850 through 2005, and were forced by time series of solar output, greenhouse gases, aerosols, and volcanic activity. The five ensemble members differ only in their initial conditions, as each member was branched off at a different time from a pre-industrial control integration. Some analyses focus on a single ensemble member, referred to as 005, which is representative of the ensemble in many aspects; for instance, according to one metric discussed below, the variance in sea level pressure explained by the southern annular mode is closest to the ensemble mean (EOF 1 in Table 2; see section 3b).

The ocean component of CCSM4 is the Parallel Ocean Program (POP; Smith et al. 2010), originally developed at Los Alamos National Laboratory, with more recent work on parameterizations done largely at the National Center for Atmospheric Research. It has a zonal grid spacing of $1.125^{\circ}$ and a meridional spacing of $0.534^{\circ}$ in the Southern Ocean and 60 levels in the vertical. See Danabasoglu et al. (2012) for a more detailed description of the ocean model configuration. Monthly-mean data fields were made available through the Earth System Grid (ESG; http:// www.earthsystemgrid.org).

\section{Surface climatology}

\section{a. Mean state and twentieth-century trends}

Figure 2a shows the difference in sea surface temperature (SST) between the 20C ensemble mean and the observational Extended Reconstructed Sea Surface Temperature analysis (ERSSTv3b; Smith et al. 2008). The seasonally ice-covered regions are mildly colder $\left(\Delta \mathrm{SST}>-2^{\circ} \mathrm{C}\right.$ ) than observations, which is consistent with the fact that sea ice extent is significantly larger 
a)

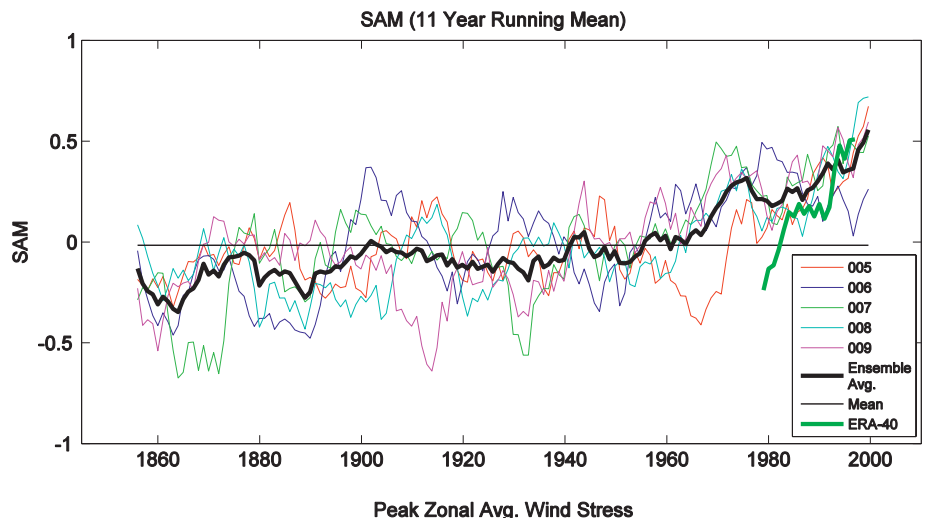

b)

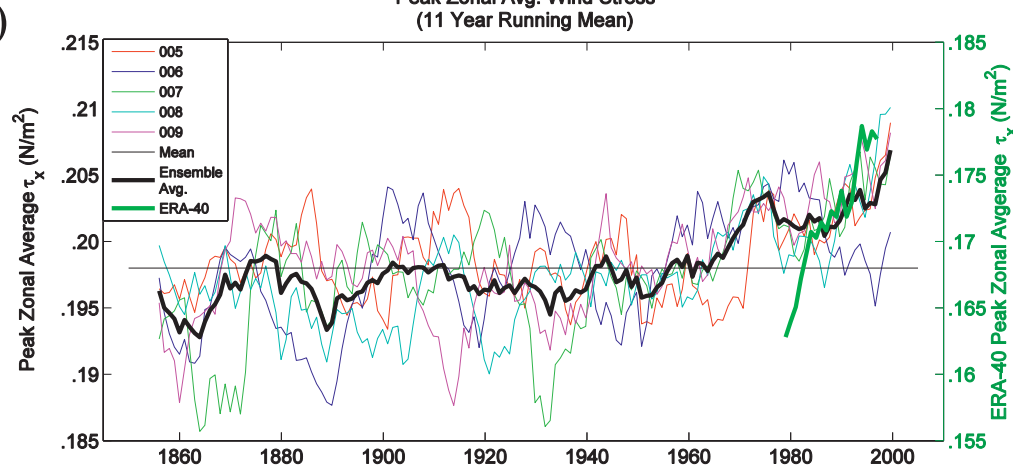

c)

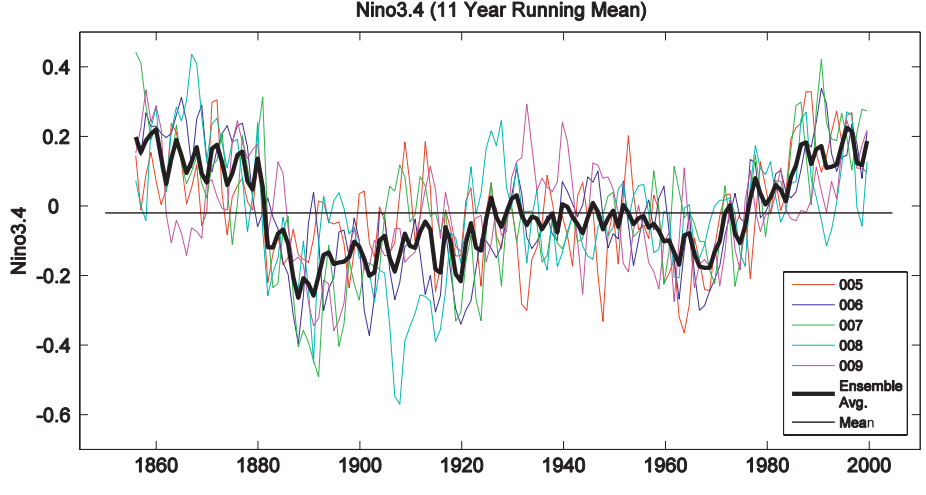

d)

Avg. Total Surface Heat Flux

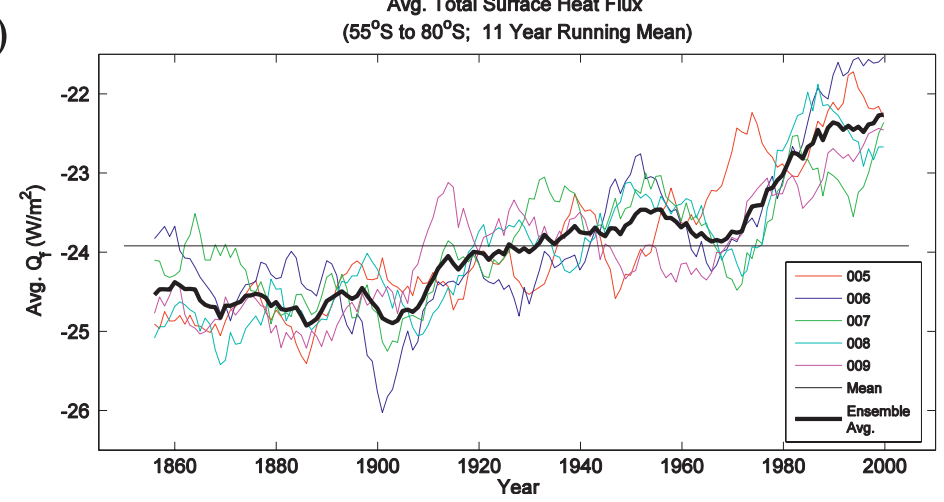

FIG. 3. Time series of (a) SAM, (b) maximum of the zonally averaged zonal wind stress, (c) the Niño-3.4 index, and (d) net SHF $Q_{f}$ averaged over the domain south of $55^{\circ} \mathrm{S}$. Plotted are 11-yr running means for the ensemble average (thick black) and each ensemble member (005-009) individually, as well as for the ERA-40 reanalysis [thick green solid; (a) and (b) only]. Thin horizontal lines indicate the 156-yr means. 
than observed (Landrum et al. 2012). North of the seasonal ice edge, there is a strong $\left(-4^{\circ}<\Delta \mathrm{SST}<-1^{\circ} \mathrm{C}\right)$ cold bias in the entire Pacific sector south of $50^{\circ} \mathrm{S}$ and in the western Australian-Antarctic Basin, while positive biases $\left(1^{\circ}<\Delta \mathrm{SST}<4^{\circ} \mathrm{C}\right)$ are found in the Indian and Atlantic sectors of the Southern Ocean. The Argentine Basin features a strong dipole at the Brazil-Malvinas Confluence (see section 5e).

The cold SST bias in large parts of the Southern Ocean is related to a significant bias in zonal wind stress, as the westerlies driving the Southern Ocean circulation in the model are substantially stronger than observed (Danabasoglu et al. 2012): zonally averaged zonal wind stress $T_{x}$ peaks at about $0.20 \mathrm{~N} \mathrm{~m}^{-2}$, as compared with approximately $0.15 \mathrm{~N} \mathrm{~m}^{-2}$ for the 40 -yr European Centre for Medium-Range Weather Forecasts (ECMWF) ReAnalysis (ERA-40) (Fig. 3b; Uppala et al. 2005).

The late twentieth-century trend in SST shows substantial and ubiquitous warming in the Subantarctic region (region north of the Antarctic Circumpolar Current; Fig. 2b), and the model trends are significantly larger than observed SST trends (Figs. 2c,d). The model warming trends may account for significant reductions in sea ice extent in most of the 20C ensemble members, although even the late twentieth-century sea ice extent is still significantly larger than observed (Landrum et al. 2012).

Significant trends are present in many other metrics (Fig. 3; Table 1). Despite large ensemble spread and interannual variability, several features appear consistently among ensemble members. This suggests a common response to external forcing variability like greenhouse gasses or ozone concentrations. The most obvious characteristic shared by most ensemble members is a post-1940 transition toward the positive phase of the SAM [Fig. 3a; defined here according to Gong and Wang (1999) as the difference of the normalized time series of monthly, zonally averaged sea level pressure between $40^{\circ}$ and $\left.65^{\circ} \mathrm{S}\right]$ and an associated strengthening of the zonal winds (Fig. 3b). For the period 1979-2005 (for which the ERA40 reanalysis was shown to perform well in the Southern Ocean; Marshall 2003; Bromwich and Fogt 2004), the ensemble mean of $T_{x}$ increases by $0.036 \mathrm{~N} \mathrm{~m}^{-2}$ with ensemble extremes of $-0.019 \mathrm{~N} \mathrm{~m}^{-2}$ (006) and 0.070 $\mathrm{N} \mathrm{m}^{-2}(005)$. The trend in the ERA-40 reanalysis data $\left(0.049 \mathrm{~N} \mathrm{~m}^{-2}\right)$ therefore falls comfortably within the ensemble spread. Similarly, the SAM strengthens on average by $0.020 \mathrm{yr}^{-1}$ with extremes of -0.009 and $0.038 \mathrm{yr}^{-1}$. This is not inconsistent with the 0.023 and $0.029 \mathrm{yr}^{-1}$ trends in the observational SAM indices of Marshall (2003) and Visbeck (2009), respectively. The trend in the ERA-40 reanalysis of $0.037 \mathrm{yr}^{-1}$ is on the high side of the ensemble.
TABLE 1. Trends in the SAM index and the peak zonally averaged zonal wind stress $T_{x}$ in the Southern Ocean for the period 1979-2005 (1979-2002 for ERA-40). Here the SAM indices were calculated according to Gong and Wang (1999) as the difference of the normalized time series of monthly, zonally averaged sea level pressure between $40^{\circ}$ and $65^{\circ} \mathrm{S}$. A linear fit was applied to the annually averaged time series to estimate the trend.

\begin{tabular}{lrc}
\hline \multicolumn{1}{c}{ Dataset } & SAM $\left(\mathrm{yr}^{-1}\right)$ & $T_{x}\left(\mathrm{~N} \mathrm{~m}^{-2}\right.$ century \\
\end{tabular}

The low-pass-filtered Niño-3.4 index (detrended time series of area-weighted SST anomalies in the traditional Niño 3.4 region $5^{\circ} \mathrm{S}-5^{\circ} \mathrm{N}, 170^{\circ}-120^{\circ} \mathrm{W}$; Trenberth 1997) starts off in positive phase during the first decades of integration, then drops off to a slightly negative level before starting a significant upswing in the last decades of the twentieth century (Fig. 3c). This behavior is obviously related to the response of globally averaged surface temperatures to external forcing (in particular volcanic, solar, and anthropogenic forcing; Ammann et al. 2003; Meehl et al. 2004; Gent et al. 2011), rather than changes in the amplitude or frequency of the ENSO phenomenon. The timing of the upswing from the late 1960s is also reflected in the net surface heat flux averaged over the region south of $55^{\circ} \mathrm{S}$ (Fig. 3d).

\section{b. Dominant modes of interannual variability}

An empirical orthogonal function (EOF) analysis of sea level pressure (SLP) is performed to study the dominant modes of interannual variability in the Southern Ocean (Fig. 4; Table 2). The EOF analysis is applied to the region south of $30^{\circ} \mathrm{S}$. The monthly data are annually averaged, detrended, and area-weighted to account for converging meridians. For the ERA-40 reanalysis (Uppala et al. 2005), only the data from 1979 have been used because of data quality concerns before that period (Marshall 2003; Bromwich and Fogt 2004). The full 156-yr period is used for the ensemble members.

The variability is dominated by the SAM (EOF 1). In the five 20C ensemble members of CCSM4, the SAM dominates interannual variability at levels between $36 \%$ and $47 \%$, with an ensemble average of $42.3 \%$ (Table 2). The ERA- 40 reanalysis assigns $41.0 \%$ of the variance to this mode. Comparison of the spatial patterns (Fig. 4) shows an excellent agreement between the model and the reanalysis. The mode is characterized by a negative 
CCSM4
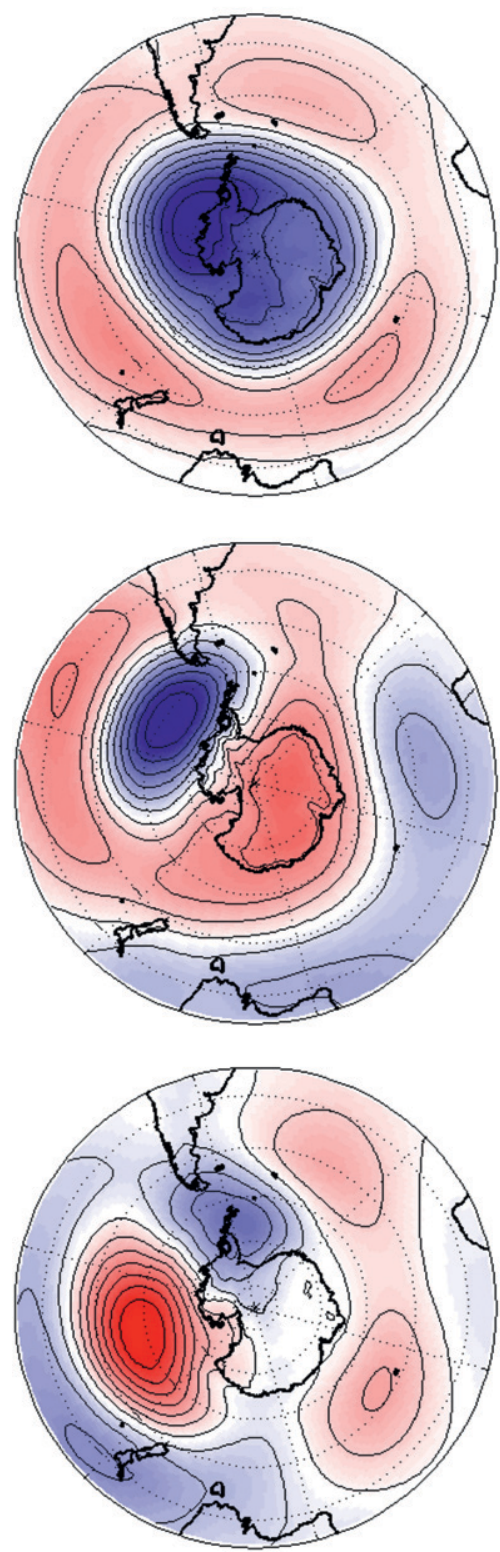

ERA-40

EOF 1

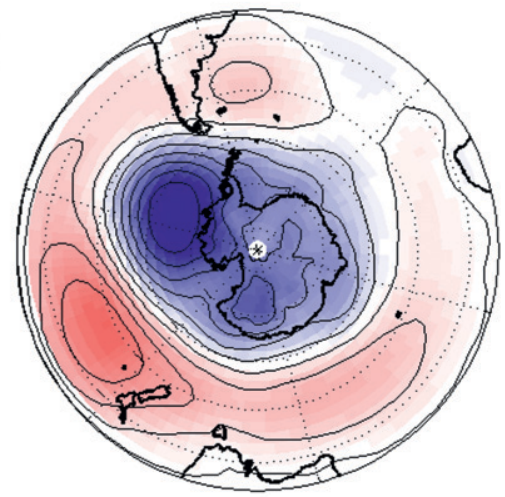

EOF 2

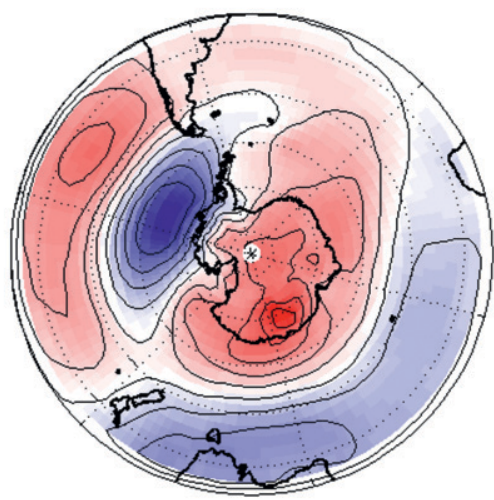

EOF 3

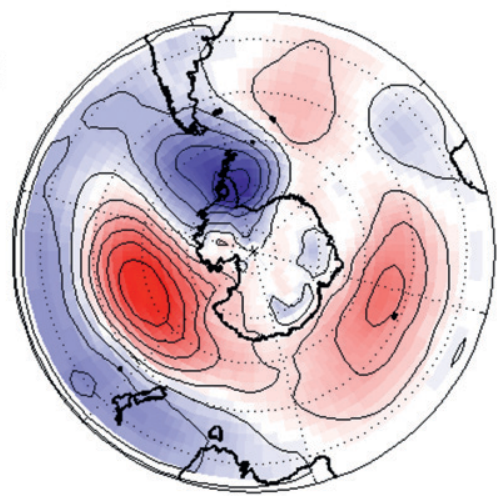

FIG. 4. Dominant EOFs of annual-mean, area-weighted sea level pressure south of $30^{\circ} \mathrm{S}$ for

(left) the ensemble average and (right) the 1979-2002 period of the ERA-40 reanalysis.

surface pressure anomaly over Antarctica, with the strongest anomaly over the Amundsen-Bellingshausen Basin. This anomaly is surrounded by an annulus of positive anomalies with a zonal wavenumber 3 pattern. The reanalysis shows a zonal asymmetry in this annulus that is not reproduced by the models, with strongest amplitude in the southwestern Pacific, and even negative anomalies (breaching the annulus) in the Atlantic sector. The CCSM4 pattern is very similar to the SAM simulated by CCSM3 (Raphael and Holland 2006).
The second and third EOFs account on average for $13.4 \%$ and $10.1 \%$ of the variance in the ensemble members, comparing well with the $15.1 \%$ and $8.2 \%$ as found in ERA-40. Again, the spatial patterns show an excellent agreement with the reanalysis-in particular regarding the strength and location of the anomalies in the southeast Pacific and the Drake Passage region. The patterns reflect the well-known PSA modes, which are quasi-stationary Rossby wave trains forced by equatorial processes (e.g., Mo and Ghil 1987; Ghil and Mo 
TABLE 2. Variance (\%) captured by the dominant EOFs of annualmean, detrended, area-weighted sea level pressure south of $30^{\circ} \mathrm{S}$ for the five 20C ensemble members, and the 1979-2002 period of the ERA-40 reanalysis (Uppala et al. 2005). Number in parentheses gives the lag- 0 correlation between the PC and the Niño-3.4 index (both detrended). Niño-3.4 index for observations is based on ERSSTv3b data (Smith et al. 2008).

\begin{tabular}{lccc}
\hline \hline Dataset & EOF 1 & EOF 2 & EOF 3 \\
\hline 005 & $43.9(-0.35)$ & $12.2(-0.65)$ & $9.7(-)$ \\
006 & $39.9(-0.22)$ & $12.3(-0.67)$ & $9.1(-)$ \\
007 & $44.5(-0.37)$ & $13.5(-0.71)$ & $10.3(-)$ \\
008 & $36.0(-0.38)$ & $15.6(-0.61)$ & $13.3(0.13)$ \\
009 & $47.0(-0.43)$ & $13.3(-0.59)$ & $8.2(-)$ \\
Ensemble & 42.3 & 13.4 & 10.1 \\
ERA-40 & $41.0(-0.41)$ & $15.1(-0.61)$ & $9.3(-)$ \\
\hline
\end{tabular}

1991; Mo and Higgins 1998). The time series associated with EOF 2 [principal component 2 (PC 2)] are significantly anticorrelated with the Niño-3.4 index (Table 2). This suggests that this mode of variability is indeed a direct response to the ENSO mode of tropical Pacific climate variability, with a positive ENSO phase (El Niño) associated with a high-pressure anomaly over the AmundsenBellingshausen Seas (e.g., Karoly 1989; Turner 2004). Coherence analysis between PCs 2 and 3 shows that these time series are generally in quadrature for the interannual periods associated with ENSO.

\section{c. Impacts of ENSO and SAM}

Figure 5 shows the correlation maps between several annually averaged fields and annual Niño-3.4 and SAM indices, averaged over the ensemble members. Here the SAM indices are based on the leading EOF of annualmean SLP for each ensemble member (as discussed in the previous section; Table 2). The ensemble means have been removed to focus on internal variability. The correlation between Niño 3.4 and zonal wind stress shows a characteristic dipole pattern with negative correlations in the Bellingshausen Basin and positive correlations in the Australian-Antarctic Basin (Fig. 5a). This pattern appears consistent with the second EOF of SLP (Fig. 4), the time series of which were found to be strongly correlated with Niño 3.4. SST variability in the Southern Ocean associated with ENSO displays a wavenumber 2 structure (Fig. 5c). Highest correlations are found in the Pacific sector, while negative correlations are found in the Atlantic. The SST anomalies are consistent with the anomalous Ekman transports implied by the wind stress anomalies, and are amplified by the anomalies in surface heat flux (SHF; per convention, SHF is positive into the ocean; Fig. 5e).

The SAM exerts a strong influence on the strength and poleward location of the maximum zonal wind stress
(Fig. 5b). Maximum correlations in the circumpolar belt exceed 0.8 in places, while farther north, anticorrelations reach values below -0.6 . The AmundsenBellingshausen Basin has the strongest deviation from pure zonality, and here the correlations are highest, in contrast to the study by Hall and Visbeck (2002), where highest correlations were found in the Indian sector of the Southern Ocean. The correlation between SST and SAM variability is to lowest-order annular in structure, but exhibits significant zonal variations. Positive SST anomalies associated with SAM are typically found north of $50^{\circ} \mathrm{S}$ (Fig. 5c), while a significant negative anomaly is found in the Pacific sector of the Southern Ocean. This is in contrast to the behavior found by Sen Gupta and England (2006) in CCSM2, where SST response to SAM has a clear annular structure, although an observational assessment by these authors shows zonal variability comparable to that found here.

CCSM4 boasts a much improved representation of ENSO. Despite an amplitude that is stronger than observed, ENSO in CCSM4 now displays variability between 3 and $6 \mathrm{yr}$, in contrast to the regular 2-yr cycle in previous versions of the CCSM (Gent et al. 2011). It is likely that this improved representation of ENSO leads to a stronger impact of ENSO on the SAM, and that the two modes of variability are more strongly coupled. This hypothesis is supported by the strong similarity between the SST responses to ENSO and SAM (Figs. 5c,d) and significant anticorrelations between the SAM and Niño3.4 indices (numbers in brackets in EOF 1 column; Table 2), which are consistent with observations (l'Heureux and Thompson 2006; Fogt and Bromwich 2006; Fogt et al. 2011). In fact, the strong impact of SAM on SSTs in the Pacific sector of the Southern Ocean is in part due to the association with ENSO. Correlations (not shown) between SST and a residual SAM index $\left(\mathrm{SAM}_{R}\right)$, constructed by subtracting the linear regression of the Niño3.4 index on SAM, show a reduced emphasis on the anomalies in the Pacific sector of the Southern Ocean, leading to a more annular structure overall.

Based on the linear regression of the SAM index on the SST fields (Fig. 5d), we can check to what extent the surface warming signal in Fig. $2 \mathrm{~b}$ can be explained by the secular strengthening of the SAM (Fig. 3a). It is found that the trend in SAM explains only a small fraction of the overall warming, but that it is responsible for some of the spatial variability of the trends in SST (not shown). In the Atlantic and Indian sectors of the Southern Ocean, SAM-related warming of about $0.2^{\circ}-0.4^{\circ} \mathrm{C}$ accounts for roughly $15 \%$ of the ensemble mean SST trend, whereas cooling between $0.2^{\circ}$ and $0.6^{\circ} \mathrm{C}$ in the Pacific sector counteracts the warming trends. This suggests that the trends in SST cannot be attributed to 
a)

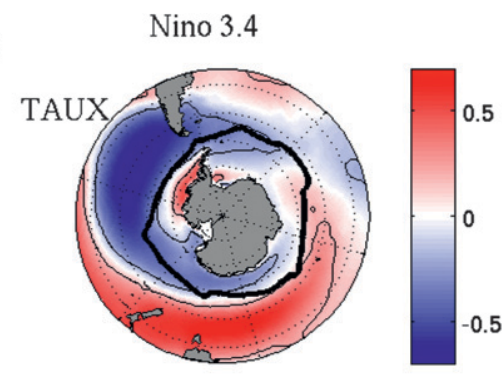

c)

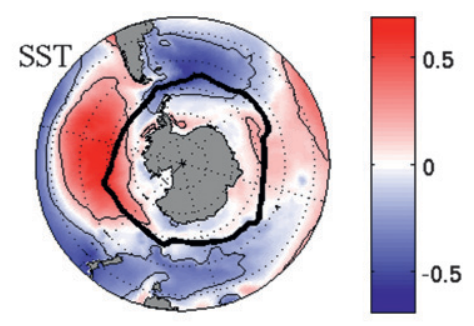

e)

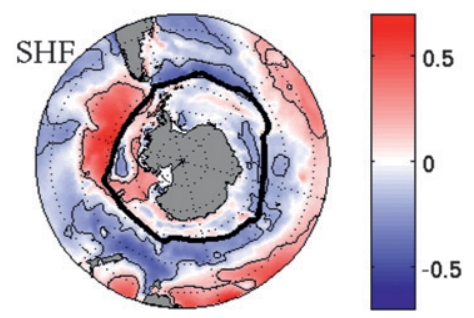

b)

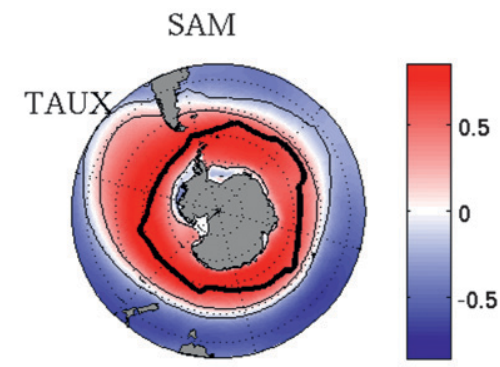

d)

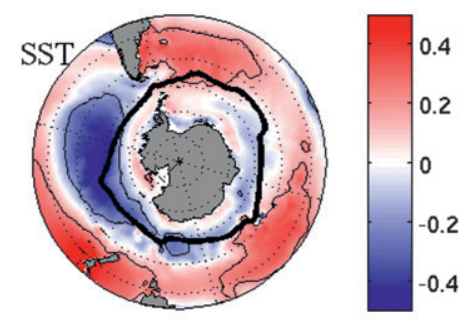

f)

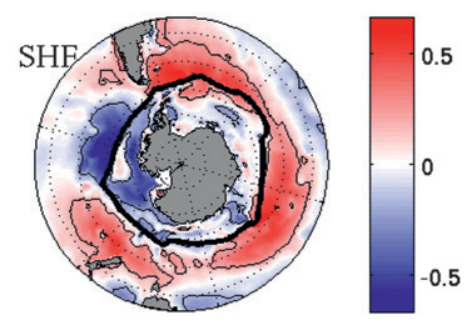

FIG. 5. Ensemble average of the correlation coefficients between the (left) Niño-3.4 and (right) SAM indices, and annually averaged (a),(b) zonal wind stress, (c),(d) SST, and (e),(f) SHF (positive into the ocean). Variables are detrended by removing the ensemble mean. Thin contours represent $95 \%$ confidence interval and thick black contour reflects ensemble average maximum ice extent over the 1968-2005 period.

secular changes in this mode of variability. Enhanced atmospheric temperatures due to changes in external forcing must be held responsible for warming of the surface ocean (Bates et al. 2011, manuscript submitted to J. Climate).

\section{Southern Ocean water masses}

\section{a. Temperature and salinity properties}

To evaluate the representation of the major Southern Ocean water masses (AABW, AAIW, and SAMW) in CCSM4, a comparison is made with the Commonwealth Scientific and Industrial Research Organisation (CSIRO) Atlas of Regional Seas 2009 (CARS2009) climatology. CARS2009 is a climatology of ocean water properties, and consists of a gridded average seasonal cycle based on a quality-controlled archive of all available historical subsurface ocean data (Ridgway et al. 2002). Details of
CARS2009 can be found at http://www.marine.csiro. $\mathrm{au} / \sim$ dunn/cars2009/.

CCSM4 depth-latitude potential temperature $\theta$, salinity $S$, and neutral density $\gamma^{n}$ distribution are compared with the CARS2009 climatology in the Atlantic $\left(335^{\circ} \mathrm{E}\right)$, Indian $\left(95^{\circ} \mathrm{E}\right)$, western $\left(190^{\circ} \mathrm{E}\right)$, and eastern $\left(260^{\circ} \mathrm{E}\right)$ Pacific sectors of the Southern Ocean (Fig. 6). Significant temperature and salinity differences between CCSM4 and CARS2009 on depth surfaces are found northward of $55^{\circ} \mathrm{S}$ and above $1000 \mathrm{~m}$ ( or $\gamma^{n}<$ $\left.27.5 \mathrm{~kg} \mathrm{~m}^{-3}\right)$ in all basins. The most significant differences are found in the Indian and Pacific sectors north of the ACC, with the CCSM4 model being too cold $\left(<-2^{\circ} \mathrm{C}\right)$ and fresh $(<-0.3 \mathrm{psu})$. This results in the model not producing the correct vertical density distribution in the upper ocean $(0-1500 \mathrm{~m})$.

Southward of approximately $50^{\circ} \mathrm{S}$, the salinity difference between CCSM4 and CARS2009 is larger than 
a)

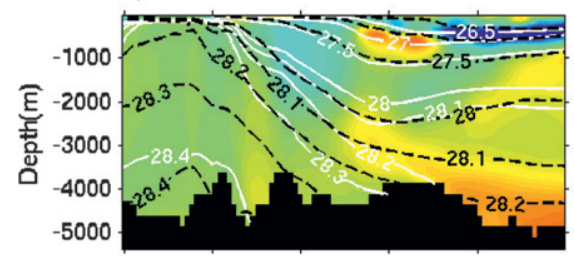

c)

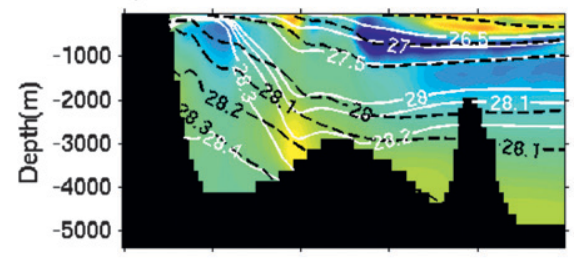

e)

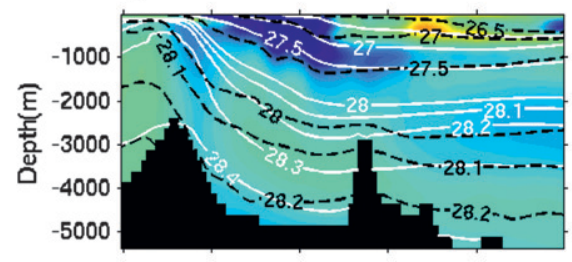

g)

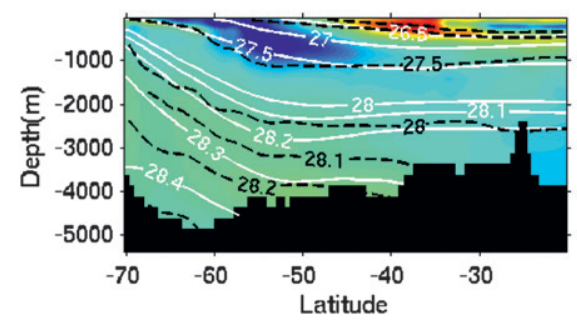

b)

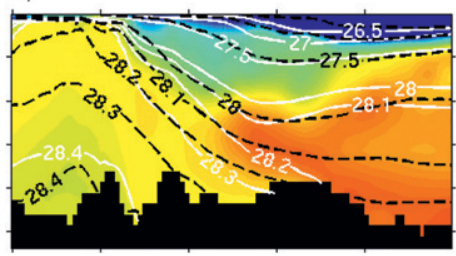

d)
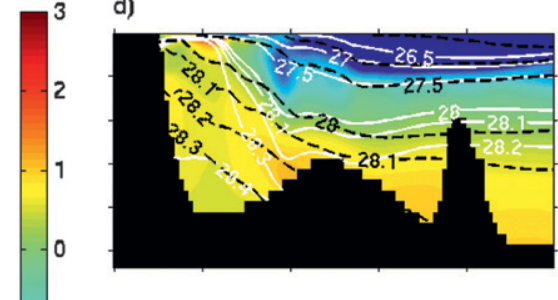

f)

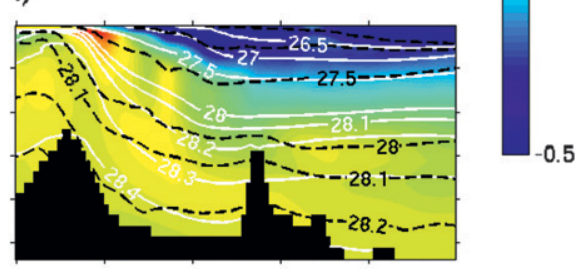

h)

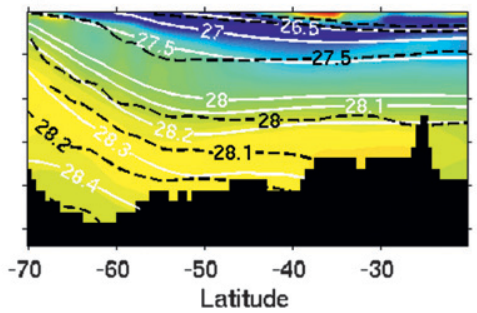

FIG. 6. CCSM4 minus (left) CARS2009 potential temperature $\left(\theta ;{ }^{\circ} \mathrm{C}\right)$ and (right) salinity $(S ;$ psu) differences for $(\mathrm{a}),(\mathrm{b})$ the Atlantic $\left(335^{\circ} \mathrm{E}\right),(\mathrm{c}),(\mathrm{d})$ Indian $\left(95^{\circ} \mathrm{E}\right),(\mathrm{e}),(\mathrm{f})$ western Pacific $\left(190^{\circ} \mathrm{E}\right)$, and $(\mathrm{g}),(\mathrm{h})$ eastern Pacific $\left(260^{\circ} \mathrm{E}\right)$ sectors of the Southern Ocean. Also shown are neutral density $\left(\gamma^{n} ; \mathrm{kg} \mathrm{m}^{-3}\right)$ for CCSM4 (white) and CARS2009 (dashed black). Location of each section is shown in Fig. 8.

0.2 psu. The salinity differences are largest in the Weddell Sea (Fig. 6b) and at the southern boundary of the Australian-Antarctic Basin in the Indian sector (Fig. 6d). As a result, $\mathrm{AABW}$ adjacent to the Antarctic continent is too dense in comparison with CARS2009.

In the Atlantic sector north of $50^{\circ} \mathrm{S}$, the difference in salinity and temperature of the abyssal and deep waters reflect the model biases in the both $\mathrm{AABW}$ and North Atlantic Deep Water (NADW) properties. NADW $(2000-3000 \mathrm{~m})$ is too salty $(>0.2 \mathrm{psu})$, resulting in the Atlantic Ocean being denser than observed by about $0.1 \mathrm{~kg} \mathrm{~m}^{-3}$ in this depth range (Fig. 6b). Below $4000 \mathrm{~m}$, the temperature and salinity differences between CCSM4 and CARS2009 are greater than $2^{\circ} \mathrm{C}$ and $0.3 \mathrm{psu}$, and the model abyssal density is lighter than observed. The South Atlantic abyssal oceans have the largest temperature and salinity difference because no Weddell Sea AABW penetrates into the Atlantic Ocean north of $40^{\circ} \mathrm{S}$ (Figs. $6 a, b)$. In the Indian and Pacific sectors of the Southern Ocean, north of $50^{\circ} \mathrm{S}$ and below $3000 \mathrm{~m}$, the too-salty AABW penetrates northward (Fig. 6), resulting in a denserthan-observed abyssal ocean in CCSM4.

Temperature-salinity diagrams in the Atlantic, Indian, eastern, and western Pacific sectors of the Southern Ocean clearly show the differences between the properties of the model and observed climatologies (Fig. 7). For $\gamma^{n}>28.0 \mathrm{~kg} \mathrm{~m}^{-3}$, the CCSM4 water masses are more salty than observed and, for $\gamma^{n}<27.5 \mathrm{~kg} \mathrm{~m}^{-3}$, there is an offset of the temperature-salinity curve with CCSM4 shifted to colder and fresher properties on a given density horizon. For SAMW and AAIW (observed density range $27.5>\gamma^{n}>26.5 \mathrm{~kg} \mathrm{~m}^{-3}$ ), the model has colder and 
a)

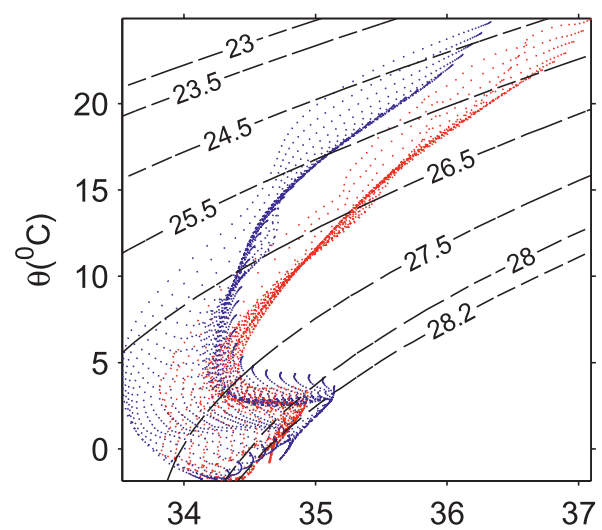

c)

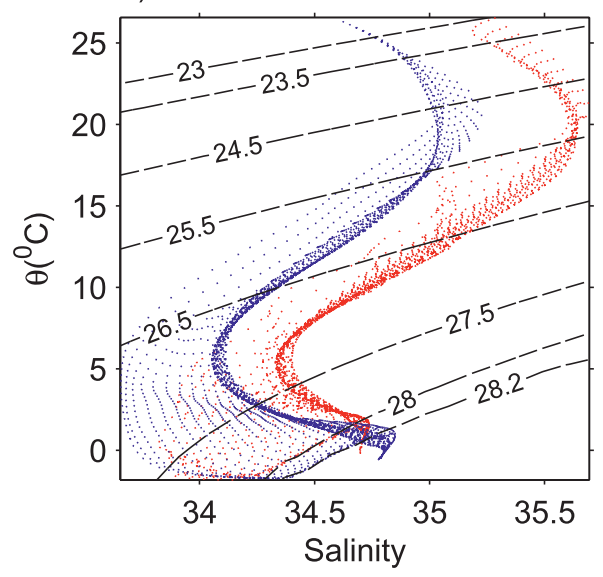

b)

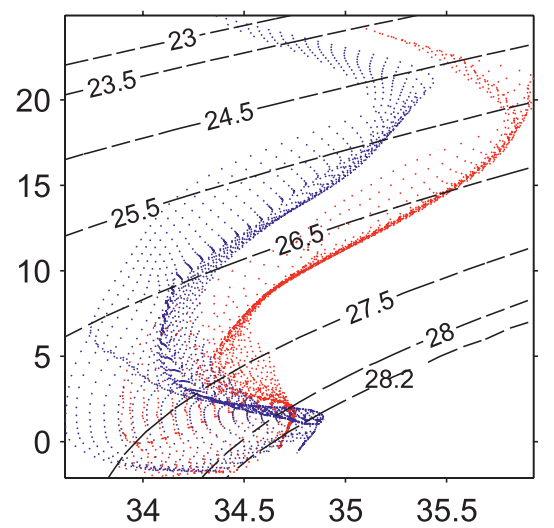

d)

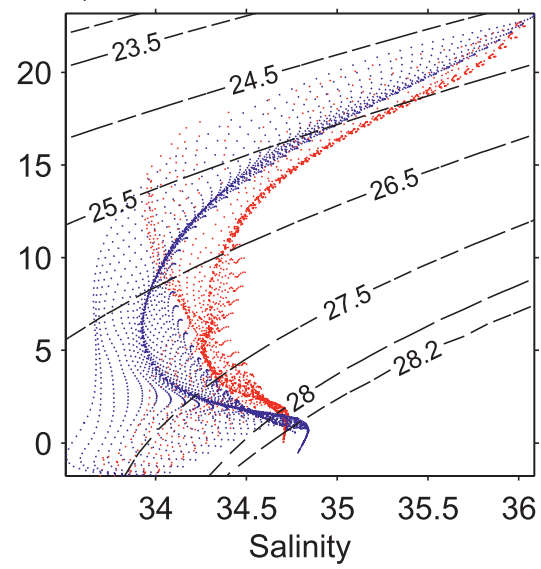

FIG. 7. Annual mean potential temperature $\left(\theta ;{ }^{\circ} \mathrm{C}\right)$ and salinity $(S ;$ psu) for CARS2009 (red) and CCSM4 (blue) for (a) the Atlantic $\left(335^{\circ} \mathrm{E}\right),(\mathrm{b})$ Indian $\left(95^{\circ} \mathrm{E}\right),(\mathrm{c})$ western Pacific $\left(190^{\circ} \mathrm{E}\right)$, and (d) eastern Pacific $\left(260^{\circ} \mathrm{E}\right)$ sectors of the Southern Ocean. Also shown are neutral density $\left(\gamma^{n} ; \mathrm{kg} \mathrm{m}^{-3}\right.$; dashed black). Location of each section is shown in Fig. 8.

fresher properties. In the next section, we compare winter mixed layer depth and potential vorticity to further understand the difference between model and observed water mass characteristics of SAMW and AAIW.

\section{b. Winter mixed layer depth and potential vorticity properties}

CCSM4 simulates the position of the observed deep winter mixed layers that extend eastward from $90^{\circ}$ to $290^{\circ} \mathrm{E}$ (Figs. 8a,b). However, the model underestimates the depth of the deep winter mixed layers in the Indian and eastern Pacific sectors of the Southern Ocean north of the ACC (Fig. 12; southward displacement from $40^{\circ} \mathrm{S}$ south of Africa to $55^{\circ} \mathrm{S}$ at Drake Passage) by as much as $150 \mathrm{~m}$ (Fig. 8c). We also note that the largest mixed layer depth differences between the model and observations are found in the southern Tasman Sea and along the eastern Indian Ocean boundary. In both of these regions, the model mixed layer depth is deeper than observed by more than $400 \mathrm{~m}$.
The shoaling of a wide range of isopycnals across the Southern Ocean toward Antarctica brings Circumpolar Deep Water (CDW; $27.5<\gamma^{n}<28.2 \mathrm{~kg} \mathrm{~m}^{-3}, 2^{\circ}<\theta<$ $4^{\circ} \mathrm{C}, 34.4<S<34.8$ psu; Fig. 6$)$ close to the surface. Deep convection on the northern side of the ACC in the Indian and Pacific sectors, during winter, is associated with the formation of SAMW and AAIW and sets the properties of SAMW and AAIW that subduct into the ocean interior. As noted by Danabasoglu et al. (2012) and shown here, while changes to the formulation of the mixed layer physics from CCSM3 to CCSM4 (specifically the introduction of the mixed layer eddy parameterization; Fox-Kemper et al. 2011) improve the simulation of the mixed layer in the Labrador Sea and near Antarctica, the simulation of the winter mixed layer depth north of the ACC is degraded.

The impact of the shallower-than-observed winter mixed layer north of the ACC in CCSM4 compared with CCSM3 and observations can be clearly seen in the potential vorticity vertical distribution. CARS2009 

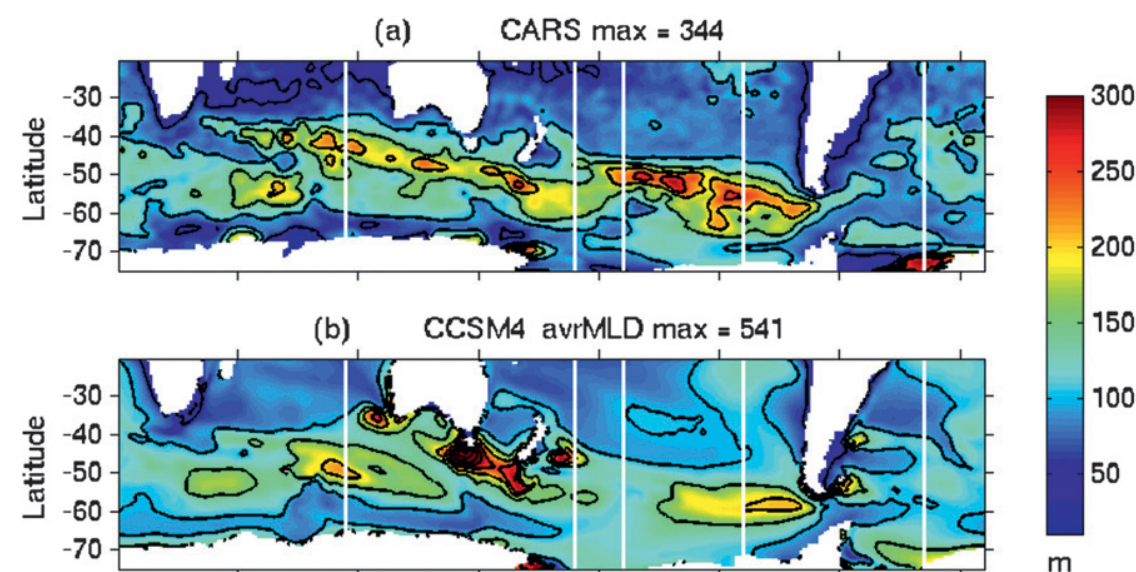

(b) CCSM4 avrMLD $\max =541$
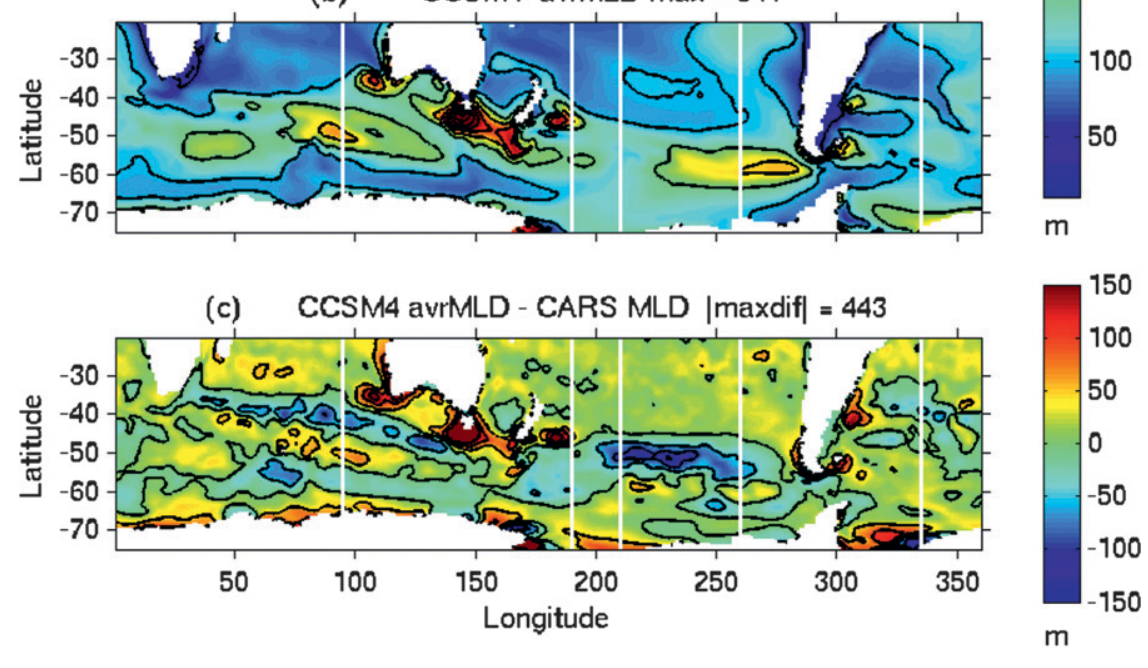

(c) CCSM4 avrMLD - CARS MLD |maxdif| = 443

FIG. 8. Winter (August-October) average mixed layer depth (m) for (a) CARS2009, (b) CCSM4, and (c) CCSM4 minus CARS2009. Also shown are the locations of sections at $335^{\circ}$, $95^{\circ}, 190^{\circ}, 210^{\circ}$, and $260^{\circ} \mathrm{E}$ (white lines) used for comparison of temperature, salinity, potential vorticity, and CFC concentration and inventory.

identifies the potential vorticity minimum of SAMW in the Indian and Pacific sectors of the Southern Ocean that extends from the winter mixed layer into the ocean interior to $25^{\circ} \mathrm{S}$ (Figs. 9b-d). CCSM4 has a potential vorticity minimum in the upper $100 \mathrm{~m}$, but this minimum does not enter the interiors of the Indian and Pacific Oceans. In CCSM3, a potential vorticity minimum $\left[<50 \times 10^{-12}(\mathrm{~m} \mathrm{~s})^{-1}\right]$ layer was found to extend to $40^{\circ} \mathrm{S}$ at approximately $600 \mathrm{~m}$ in the Indian and $500 \mathrm{~m}$ in the Pacific sectors of the Southern Ocean (Sloyan and Kamenkovich 2007). The difference between CCSM4 and CARS2009 potential vorticity distribution (Fig. 9, right panels) shows the largest differences are associated with the SAMW potential vorticity minimum, but also that large differences are found at the base of the winter mixed layer. The strong stratification at the base of the mixed layer in CCSM4 may inhibit the production of deep water mixed layers on the equatorward side of the ACC.

\section{c. Transient tracers}

Chlorofluorocarbons (CFC-11 and CFC-12) are conservative tracers in the ocean that are used to evaluate circulation and formation rates of water masses (e.g.,
Fine 2011). They provide a direct analog to the physical processes of uptake and storage of carbon in the oceans. Global CFC oceanic observations were made starting in the 1980s and continued during the 1990s as a part of the World Ocean Circulation Experiment (WOCE) and in the 2000s as a part of Climate Variability and Predictability (CLIVAR) and Global Ocean Ship-Based Hydrographic Investigations Program (GO-SHIP). These programs allow for the direct comparison of model CFC fields with hydrographic observations. Here, we compare model and observed CFC-11.

The CFC-11 distributions from observations and mean model ensemble, at approximately the corresponding dates, are compared in the Atlantic $\left(330^{\circ} \mathrm{E}, 1995\right)$, Indian $\left(90^{\circ} \mathrm{E}, 1995\right)$, and Pacific $\left(210^{\circ} \mathrm{E}, 2005\right)$ sectors of the Southern Ocean (Fig. 10). The model CFC-11 concentration in the upper ocean $(0-500 \mathrm{~m})$, poleward of where the $\gamma^{n}=26.5 \mathrm{~kg} \mathrm{~m}^{-3}$ isopycnal outcrops, is higher than observations, apart from between $65^{\circ}$ and $55^{\circ} \mathrm{S}$ in the Atlantic sector (Fig. 10). In all sectors of the Southern Ocean, model CFC-11 concentrations in the lower thermocline and intermediate waters $\left(26.5<\gamma^{n}<\right.$ $27.5 \mathrm{~kg} \mathrm{~m}^{-3}$ ) are lower than observed. Finally, model CFC-11 concentrations in the deep ocean (below $2000 \mathrm{~m}$ ) 

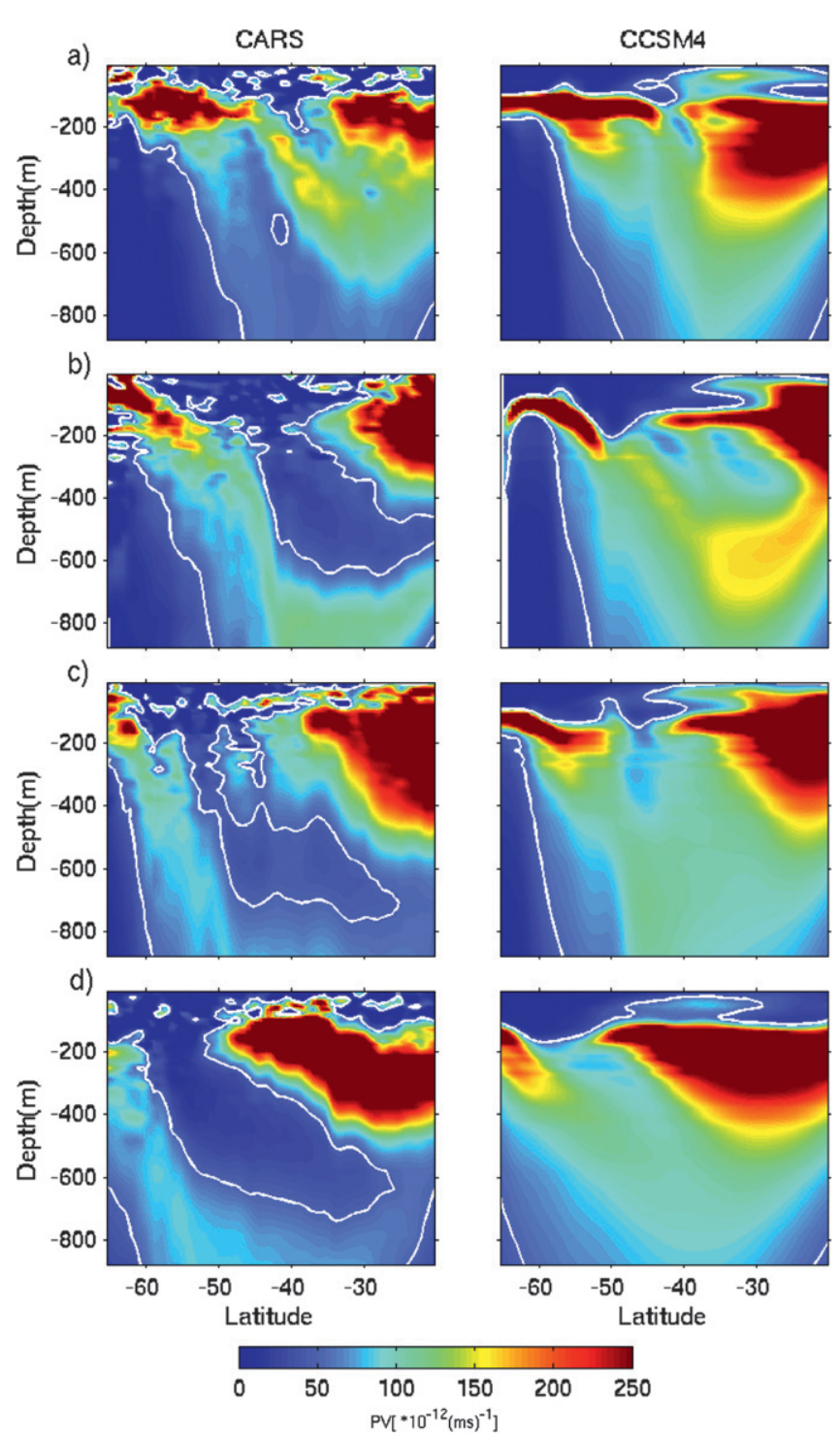
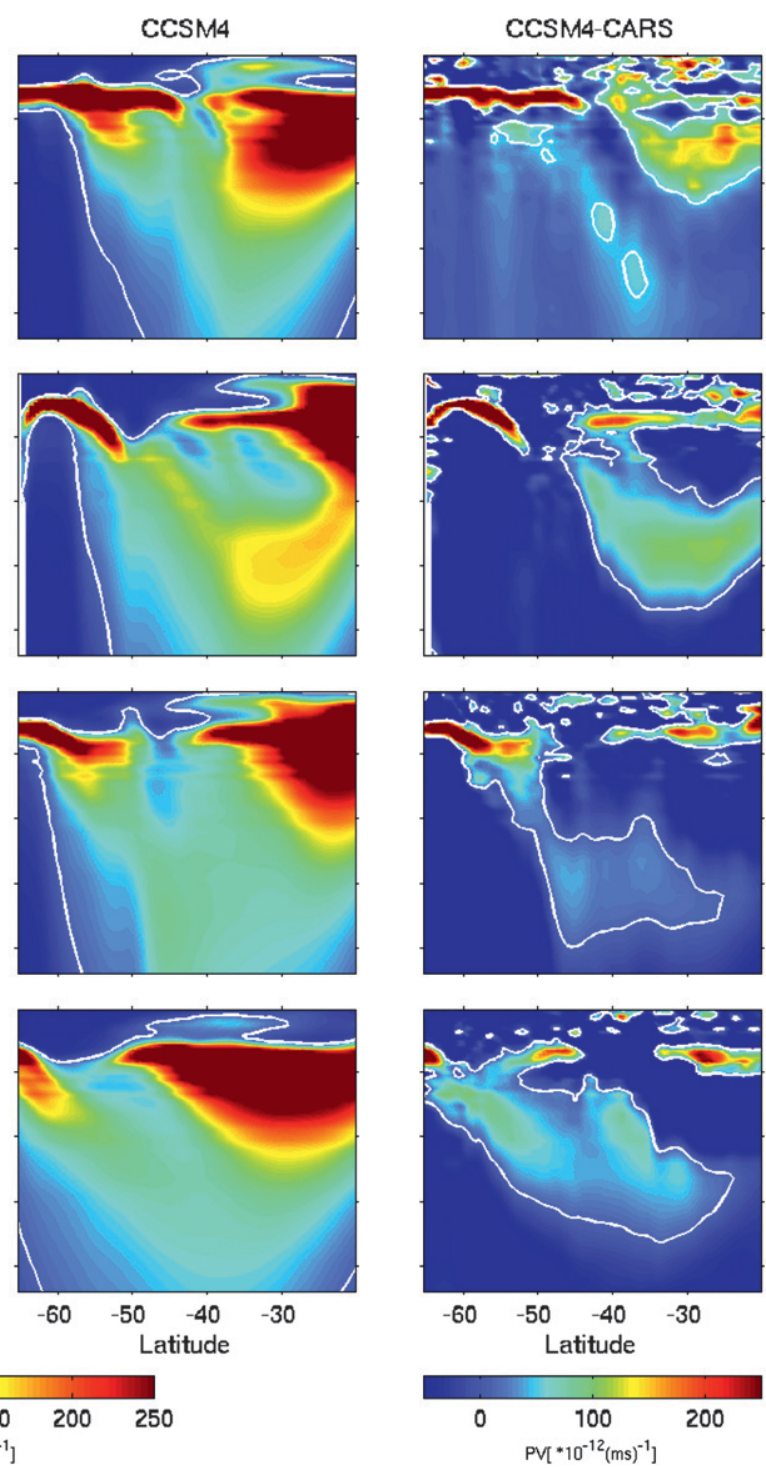

FIG. 9. Comparison of winter (August-October) potential vorticity $\left[\times 10^{-12}(\mathrm{~m} \mathrm{~s})^{-1}\right]$ for (left) CARS2009, (center) CCSM4, and (right) CCSM4 minus CARS2009 for (a) the Atlantic (335 ${ }^{\circ}$ ), (b) Indian $\left(95^{\circ} \mathrm{E}\right)$, (c) western Pacific $\left(190^{\circ} \mathrm{E}\right)$, and (d) eastern Pacific $\left(260^{\circ} \mathrm{E}\right)$ sectors of the Southern Ocean. The potential vorticity and potential vorticity difference $50 \times 10^{-12}(\mathrm{~m} \mathrm{~s})^{-1}$ (white contour) is shown on (left) and (center), and (right), respectively. Location of each section is shown in Fig. 8.

are lower than observed in the basins adjacent to the Antarctic continent. We also note that these low model CFC-11 concentrations extend from $500 \mathrm{~m}$ to the ocean sea floor south of $60^{\circ} \mathrm{S}$ in the Atlantic sector. Differences in the model and observed CFC concentration emphasize the potential for further model improvement in ocean-atmosphere exchange and upper-ocean parameterizations.

While the comparison of model and observed CFC-11 concentrations is useful, comparison of model and observed water mass CFC-11 inventories provides an integrated assessment of the model CFC-11 simulation (Fig. 11). The model CFC-11 inventory for surface waters $(0-500 \mathrm{~m})$ is higher than observed for the entire P16 section $\left(210^{\circ} \mathrm{E}\right)$. For the lower thermocline and intermediate waters (500-1500 m), the model CFC-11 inventories are higher than observations poleward of $55^{\circ} \mathrm{S}$ and lower than observations equatorward of $55^{\circ} \mathrm{S}$. SAMW and AAIW $\left(26.5<\gamma^{n}<27.5 \mathrm{~kg} \mathrm{~m}^{-3}\right.$; Fig. 10) are found equatorward of $55^{\circ} \mathrm{S}$ and are deficient in the model CFC-11 inventory by approximately $0.25 \mathrm{~mol} \mathrm{~km} \mathrm{k}^{-2}$. Deep water CFC-11 inventories (1500-5000 m) between 
a)

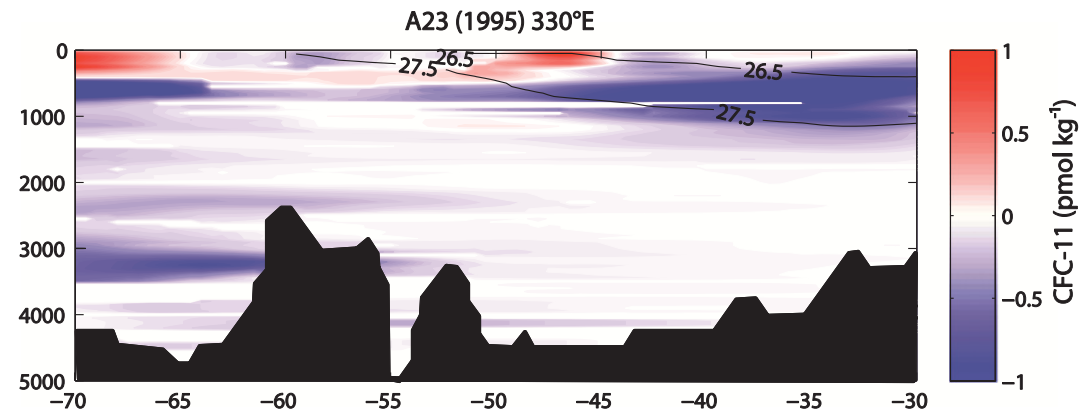

b)

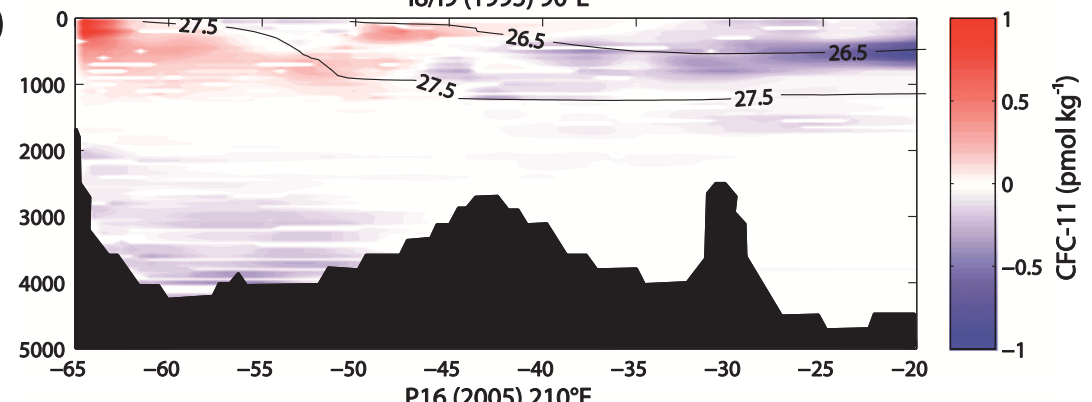

c)

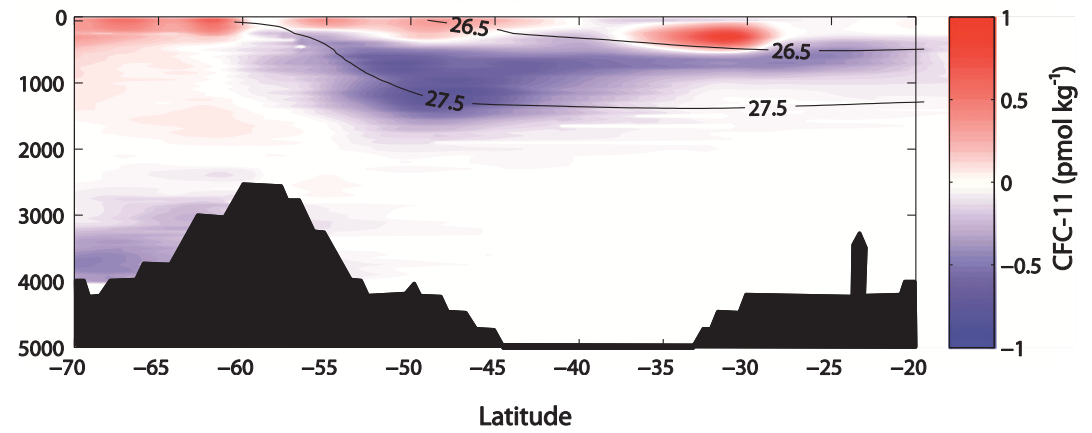

FIG. 10. Difference among model simulation and observations of CFC-11 concentrations $\left(\mathrm{pmol} \mathrm{kg}{ }^{-1}\right)$ in the (a) Atlantic $\left(330^{\circ} \mathrm{E}\right),(\mathrm{b})$ Indian $\left(90^{\circ} \mathrm{E}\right)$, and (c) Pacific $\left(210^{\circ} \mathrm{E}\right)$ sectors of the Southern Ocean. Also shown are the neutral densities (black contours) that roughly define the boundaries of SAMW $\left(\gamma^{n}>26.5 \mathrm{~kg} \mathrm{~m}^{-3}\right)$ and AAIW $\left(\gamma^{n}<27.5 \mathrm{~kg} \mathrm{~m}^{-3}\right)$.

$70^{\circ}$ and $60^{\circ} \mathrm{S}$ provide a signature of bottom water formation at the Antarctic continental shelf. The modelsimulated CFC-11 inventory is lower than observed by approximately $1 \mathrm{~mol} \mathrm{~km}^{-2}$.
Observations show that $\mathrm{CFC}-11$ ocean inventories increase in the water column with increasing time as more waters are exposed to the atmosphere. In this study, we find that model-simulated SAMW, AAIW, and AABW

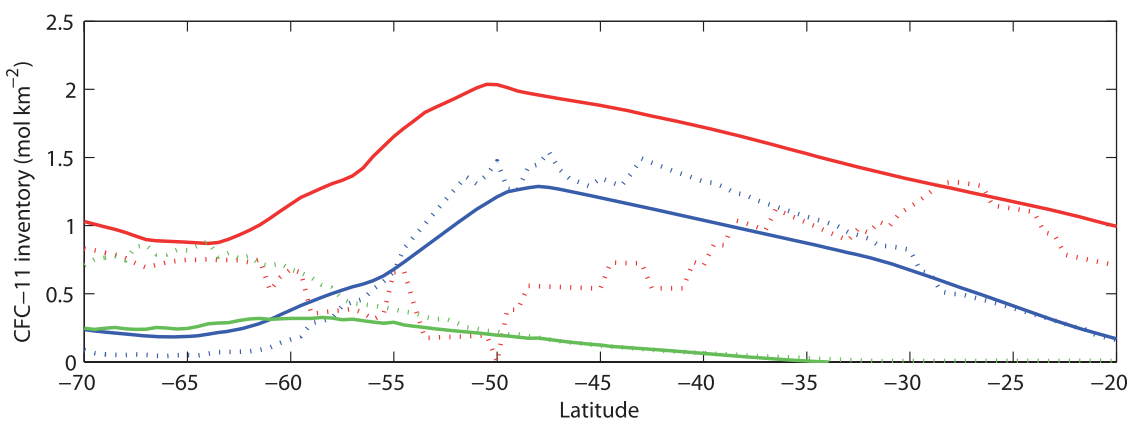

FIG. 11. CFC-11 inventory ( $\mathrm{mol} \mathrm{km}{ }^{-2}$ ) for $210^{\circ} \mathrm{E}$ (P16) in 2005 for model simulation (solid) and from observations (dashed). Inventory for different water layers are shown: 0-500 m (red), 500-1500 m (blue), and 1500-5000 m (green). 
have reduced CFC-11 concentrations compared to observations, and the model surface $\mathrm{CFC}-11$ concentrations are higher than observed. A comparison of CFC-11 concentrations along $210^{\circ} \mathrm{E}(\mathrm{P} 16)$ in 1991 and 2005 shows that model and observation differences increase with time (not shown).

There are three main biases within the model that may impact the concentration and inventory of CFC-11: temperature, mixed layer depth, and wind stress. CCSM4 has a cold temperature bias within intermediate water and deep-bottom waters (Figs. 6 and 7). A cold bias would result in greater CFC-11 concentrations compared to observations. However, we find that CFC-11 concentrations are lower than observations and therefore suspect that temperature bias is not a significant factor in the model CFC-11 simulation. As shown in Figs. 8 and 9, the austral winter mixed layer depths in CCSM4 are shallower than observed and the winter potential vorticity minimum does not penetrate into the ocean interior below $200 \mathrm{~m}$. Mixed layer depths particularly in the southeast Pacific, a major formation region for SAMW and AAIW, are underestimated by more than $50 \mathrm{~m}$ relative to CARS2009 climatology. Shallower mixed layers may result in inaccurate formation of SAMW and potentially fewer CFCs accumulating within these water masses in the ocean interior. The reduced penetration of CFC-11 in the model ocean interior may also indicate that the carbon sequestration by these water masses would be underestimated in the model simulations. Last, a stronger wind stress may result in the surface concentration of CFC-11 being overestimated, particularly north of the ACC where there is less interaction from sea ice.

\section{Southern Ocean circulation and interbasin exchange}

\section{a. Production of $A A B W$}

Newly formed shelf water mixes with ambient waters to form the AABW. This entrainment takes place mostly at overflow locations in the Weddell (Foldvik et al. 2004) and Ross Seas (Gordon et al. 2004) and along the Adélie Coast (Williams et al. 2010). This process is not well represented at the current model resolution, as it typically occurs below the grid scale of the current generation of ocean climate models. In addition, spurious mixing in $z$-level models like POP tends to dilute overflow waters (Legg et al. 2009).

In an attempt to remedy this shortcoming, CCSM4 applies a novel parameterization to the four regions where overflows are thought to play the most important role in water mass transformations (Legg et al. 2009). Two of these were assigned to the Nordic sill overflows, and the other two are applied to the Ross and Weddell Seas (Figs. 1b,c; Briegleb et al. 2010; Danabasoglu et al. 2010). The overflow parameterization (OFP) and its implementation in POP were discussed in detail by Briegleb et al. (2010). In short, the parameterization identifies source waters, which are mixed with entrainment waters to generate product waters on the downstream side of the sill. These product waters are then injected at the depth where its density matches that of the interior waters. To discourage explicitly resolved overflows, slight modifications to the bathymetry are made. Such modifications, as well as the identification of the injection locations, are subjective choices guided by observations in the overflow regions.

A detailed analysis by Danabasoglu et al. (2012) shows that in the CCSM4, the production of overflow waters in the Ross Sea is too low by about a factor of 2 $\left(1.15 \mathrm{~Sv} ; 1 \mathrm{~Sv} \equiv 10^{6} \mathrm{~m}^{3} \mathrm{~s}^{-1}\right)$ relative to the limited observations (2 Sv; Legg et al. 2009). The depth at which the product water settles was also shown to be too shallow by about a factor of 2 . In the Weddell Sea, virtually no overflow waters were produced $(5 \mathrm{~Sv}$ in observations).

Problems with the OFPs in the Antarctic waters are apparent from previous studies. In Briegleb et al. (2010), the parameterization was forced with climatological values of temperature and salinity. Production rates in the Ross Sea (1.28 Sv) were about half of observational estimates, and an order of magnitude too small $(0.28 \mathrm{~Sv})$ in the Weddell Sea. Danabasoglu et al. (2010) compared fully coupled and ocean hindcast simulations with and without OFP; in both configurations, the AABW overturning cell in the Atlantic disappeared almost completely when the OFPs were introduced. The ocean-ice hindcast simulation described in Danabasoglu et al. (2012) shows a similarly weak AABW overturning cell as the fully coupled CCSM4, suggesting that it suffers from a similar bias in AABW production rates.

The reason for the underestimation of AABW production rates is currently under investigation. Danabasoglu et al. (2012) point at significant biases in salinity and temperature of the source and entrainment waters in the Southern Ocean. The implementation of the OFP requires the choice of a number of constants (i.e., thickness of upstream source water, width of outflow strait). The lack of observations at $\mathrm{AABW}$ water formation sites and knowledge of downslope flows may have resulted in suboptimal tuning of the parameterization.

\section{b. Export of $A A B W$}

In the ocean, AABW is transported to the global abyssal ocean in deep western boundary currents east of the Kerguelen Plateau (Fukamachi et al. 2010) and off 
the Antarctic Peninsula in the Weddell Sea (Gordon et al. 2001; Fahrbach et al. 2001). The CCSM4 features a strong northward current off the Kerguelen Plateau in the Australian-Antarctic Basin (AAB; not shown). Inspection of the barotropic streamfunction (BSF) (Danabasoglu et al. 2012, their Fig. 13) suggests that this is part of a cyclonic gyre in the AAB (McCartney and Donohue 2007). Below a surface-intensified flow in the upper $500 \mathrm{~m}$, the vertical structure is barotropic and lacks the bottom intensification apparent in observations (Fukamachi et al. 2010). An estimate of the northward AABW transport $\left(\theta<0^{\circ} \mathrm{C}\right)$ across $57.6^{\circ} \mathrm{S}$ is $8.0 \pm 2.2 \mathrm{~Sv}$. This is about two-thirds of the observational estimate of $12.3 \pm 1.2 \mathrm{~Sv}$ by Fukamachi et al. (2010). A similar analysis for the Weddell Sea yielded a less satisfactory comparison with observations. At $64^{\circ} \mathrm{S}$ in the Weddell Sea-the location of an array studied by Fahrbach et al. (2001) - no waters colder than $-0.7^{\circ} \mathrm{C}$ were found (the definition for the Weddell Sea Bottom Water), and there was no sign of a deep boundary current.

It is possible that reduction or absence of $A A B W$ export pathways in the AAB and the Weddell Sea, respectively, is related to the components of the overflow parameterization. These model biases in the formation rate, overflow processes, and circulation pathways may partly explain the temperature, salinity, and density errors found in deep ocean.

\section{c. Antarctic circumpolar current transports}

The integrated transport of the ACC is known best at the Drake Passage, where Cunningham et al. (2003) report a range of $137 \pm 8 \mathrm{~Sv}$. The ensemble mean of the CCSM4 transport is substantially higher at $173 \mathrm{~Sv}$. This could be in part the result of the too-strong Southern Ocean winds. There is little long-term variation between ensemble members, with mean transports over the 156-yr period within the narrow range of 172-175 Sv, with standard deviation of $3 \mathrm{~Sv}$ for each ensemble member. Diagnosed transports (not shown) show no appreciable increase in the later years of the twentieth century, despite the increasing trend in wind stress evident in Fig. 3b. This lack of response is partially explained by Gent and Danabasoglu (2011), who show that the more sophisticated formulation of isopycnal tracer transport used in CCSM4 is consistent with the eddy saturation of circumpolar transport discussed by Hallberg and Gnanadesikan (2006).

\section{d. Antarctic circumpolar current structure}

The ACC is highly filamented and comprises a number of meandering jets with meridional scales on the order of $50 \mathrm{~km}$ (Orsi et al. 1995; Sokolov and Rintoul 2009). While eddying ocean models are able to reproduce
TABLE 3. Definition criteria for the different fronts in the Southern Ocean for the CARS2009 climatology and an individual ensemble member (005) of CCSM4. Values in parentheses denote range in east longitude.

\begin{tabular}{lll}
\hline \hline Front & \multicolumn{1}{c}{ CARS2009 } & \multicolumn{1}{c}{ CCSM4 } \\
\hline SAJ & $380-\mathrm{m}$ temperature $\left({ }^{\circ} \mathrm{C}\right)$ & $380-\mathrm{m}$ temperature $\left({ }^{\circ} \mathrm{C}\right)$ \\
& $4.5-8.0(-60-195)$ & $4.5-8.0(-60-195)$ \\
& $3.0-5.0(195-300)$ & $3.9-5.6(195-220)$ \\
& & $2.6-4.6(220-300)$ \\
NPJ & $150-\mathrm{m}$ temperature $\left({ }^{\circ} \mathrm{C}\right)$ & $380-\mathrm{m}$ temperature $\left({ }^{\circ} \mathrm{C}\right)$ \\
& $1.5-2.0(0-360)$ & $2.675-2.925(-60-80)$ \\
& & $1.675-1.925(80-180)$ \\
& & $1.50-1.75(180-220)$ \\
SPJ & $400-\mathrm{m}$ salinity $(\mathrm{psu})$ & $1.60-1.85(220-300)$ \\
& $34.6-34.7(0-360)$ & $380-\mathrm{m}$ salinity $(\mathrm{psu})$ \\
& & $34.25-34.35(-60-80)$ \\
& & $34.40-34.50(80-300)$ \\
\hline
\end{tabular}

this structure (Maltrud et al. 1998), CCSM4, with meridional grid spacing of $60 \mathrm{~km}$ in the Southern Ocean, was not designed to do so. However, since the jets are typically associated with fronts that delineate various water masses in the region, the realism of the two are directly coupled.

While two primary frontal systems in the ACC are responsible for the bulk of the eastward transport-the Subantarctic Front (SAF) and the Polar Front (PF)they may be made up of multiple distinct jets (Sokolov and Rintoul 2009) that are not usually resolved by climate models. Historically, the location of a particular isotherm or isohaline has been used to define the location of these fronts (Orsi et al. 1995), and we will use a similar technique here.

It is possible to identify three jets in the model at any given longitude- the Subantarctic jet (SAJ), Northern Polar Jet (NPJ), and Southern Polar Jet (SPJ). As in the real ocean, circumpolar each jet can vary strongly in strength and in proximity to the other jets. Similarly, several jets can be identified in the CARS2009 climatology based on the geostrophic velocity relative to $2000 \mathrm{~m}$. Generally there are more jets in the data than in the model, though not as many as identified by Sokolov and Rintoul (2009) using high frequency altimeter data.

We identify the monthly locations of the jets in both the model (year 1989 of ensemble member 005) and the CARS2009 climatology based on velocity maxima and various water mass properties (Table 3; Fig. 12). A range of temperature contours are used to qualitatively signify the amount of variability in the locations of the jets. For the data, the Orsi et al. (1995) definitions can define the locations of the SAJ, NPJ, and SPJ and temperature and salinity fronts associated with the jets. The CCSM4 jet locations are fairly realistic when compared with the data, showing similar pathways for much of their 

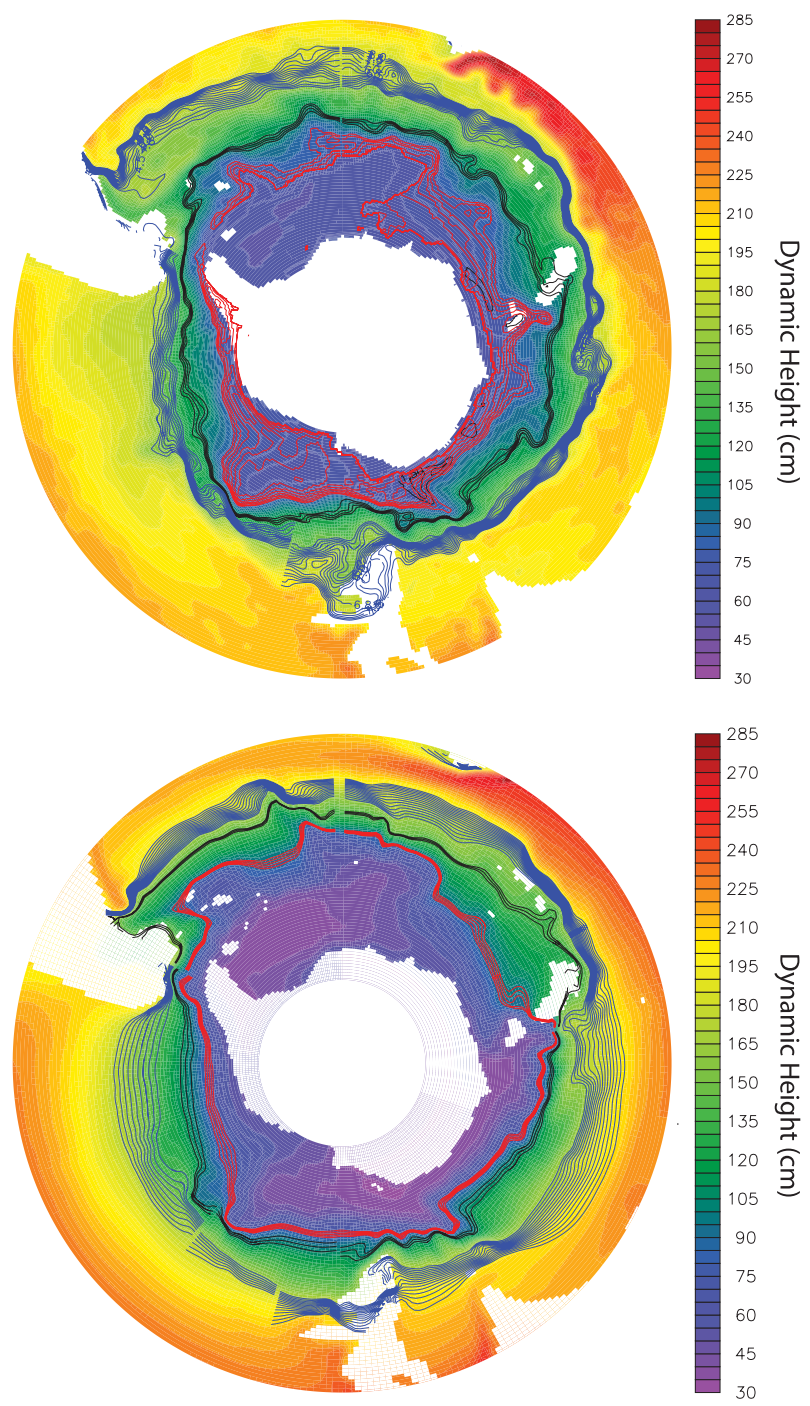

FIG. 12. Dynamic height relative to $2000 \mathrm{~m} \mathrm{(cm)} \mathrm{with} \mathrm{monthly}$ locations of ACC jets superimposed by contours denoting the SAJ (blue), NPJ (black), and SPJ (red). (top) CARS2009 seasonal climatology; (bottom) year 1989 of the 20C ensemble member 005 of CCSM4. Frontal definitions are listed in Table 3.

circumpolar extent. Unlike the data, however, it is not possible to define the model jets with small ranges in temperature or salinity for their entire circumpolar extent. When at least two of the jets are forced into close proximity with each other, typically because of topographic steering (Fig. 12; Kerguelen Plateau at $90^{\circ} \mathrm{E}$, Macquarie Ridge at $160^{\circ} \mathrm{E}$, and Eltanin Fracture at $210^{\circ} \mathrm{E}$ ), water masses are strongly mixed and different values of temperature and salinity are needed to locate the position downstream. This likely signifies that the model's mixing is excessive when jets are close together. One significant difference between the model and data is the criterion used for defining the NPJ (Fig. 12). The
NPJ typically coincides with the northern extent of the subsurface cold water tongue at $150 \mathrm{~m}$ and is well defined by temperature values between $3^{\circ}$ and $4^{\circ} \mathrm{C}$ at $150 \mathrm{~m}$. In the model, the current crosscuts isotherms at $150 \mathrm{~m}$ in areas that are not strongly steered by topography, so temperature at $400 \mathrm{~m}$ was found to represent the jet location much more consistently. This implies a significant difference in the dynamics of this jet in the model when compared with the observed ocean.

The vertical signature of the Southern Ocean jets at $105^{\circ} \mathrm{E}$ shows that, in the data, the SAJ exists at the boundary between low potential vorticity SAMW to the north and fresher water to the south (not shown). The SAMW in this region is not well simulated by the model below $200 \mathrm{~m}$ (see section 4). However, there is enough of a density gradient to support the SAJ. The NPJ and SPJ can be identified by a strong potential vorticity gradient at depth in both the data and model. Both are related to the boundary between the high potential vorticity water south of the SAF and salty Upper Circumpolar Deep Water (UCDW).

\section{e. Brazil-Malvinas Confluence region}

After passing through the Drake Passage, a branch of the ACC shoots northward as the Malvinas Current and collides with the southward-flowing Brazil Current in one of the most energetic regions in the world's oceans. Figure 2a shows that there are considerable biases in SST in this BMC region. In addition, the subtropical gyre of the South Atlantic is too strong by almost a factor of 2, associated with a strong bias in the wind stress (section 3; Danabasoglu et al. 2012). To study these biases in more detail, we compare the southwestern Atlantic in an individual CCSM4 20C ensemble member (005) with the Simple Ocean Data Assimilation (SODA) dataset (Carton and Giese 2008). Climatological SSTs and barotropic transports for January and July are shown in Fig. 13.

Because of lack of resolution, CCSM4 does not show as much spatial variability as SODA, particularly west of $50^{\circ} \mathrm{W}$ in the $\mathrm{BMC}$ region. The northward penetration of the colder Malvinas Current along the South American coast is seen in July to reach $34^{\circ} \mathrm{S}$ (Fig. 13, bottom-left panel), while for the SODA results (Fig. 13, bottom-right panel) the Malvinas Current penetrates farther north to $30^{\circ} \mathrm{S}$. The southward intrusion of the Brazil Current tongue of warm (salty) waters is much better defined in the SODA results. The warm bias of CCSM4 in this region is as great as $11^{\circ} \mathrm{C}$ in July, and almost $15^{\circ} \mathrm{C}$ in January, due largely to this displacement of the frontal position.

Compared to observational studies that find the BMC varying in latitudinal positions between $33^{\circ}-38^{\circ} \mathrm{S}$ (Olson et al. 1988; Garzoli and Garraffo 1989; Stramma and Peterson 1990; Jullion et al. 2010), the mean position of the BMC is too far south in the CCSM4. Using the zero 

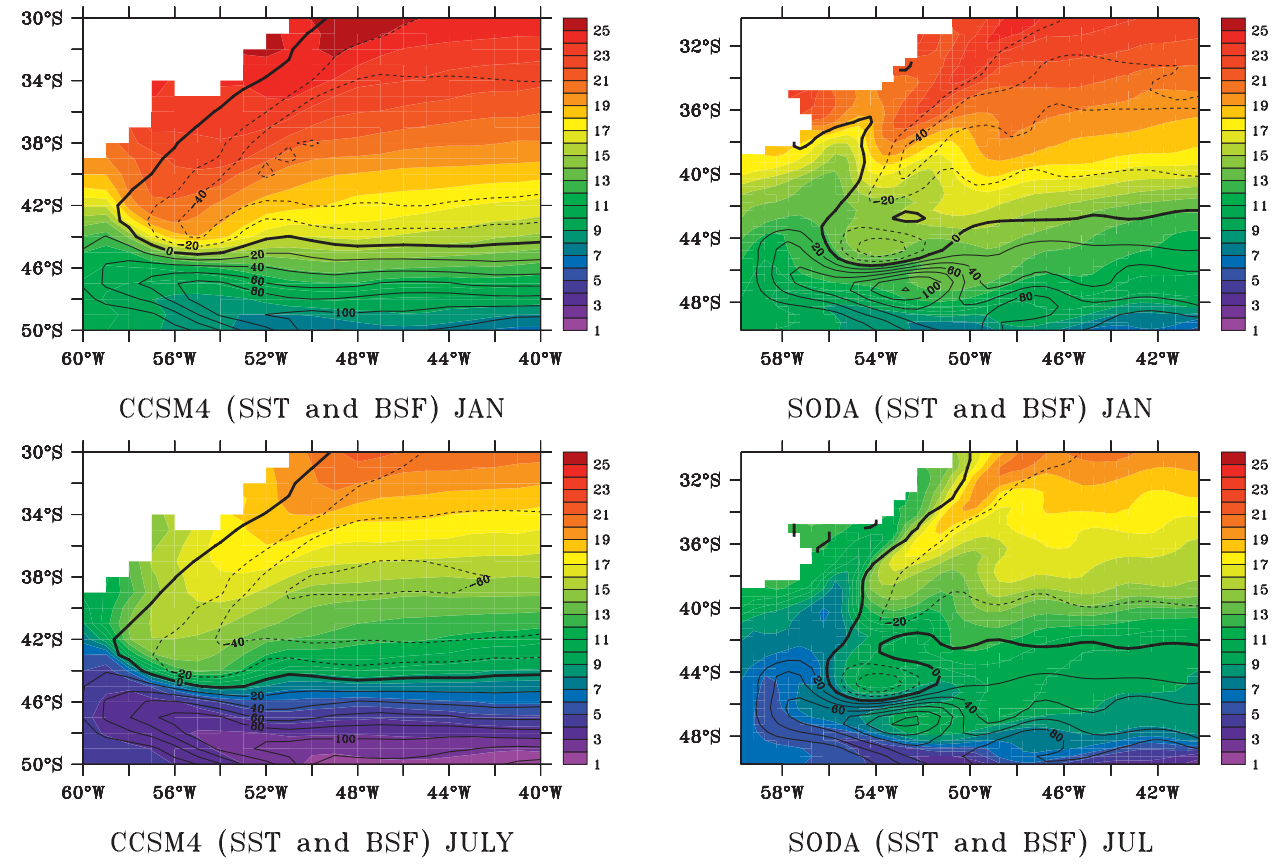

FIG. 13. Climatological SST $\left({ }^{\circ} \mathrm{C}\right.$; shading) with the BSF (Sv; contours) for the southwestern Atlantic for an individual 20C ensemble member (005) of (left) CCSM4 and (right) SODA. Climatologies are for (top) January and (bottom) July.

contour of the barotropic streamfunction to locate the BMC (Wainer et al. 2000), the mean position of the $\mathrm{BMC}$ in this specific ensemble member is $44^{\circ} \pm 0.5^{\circ} \mathrm{S}$. The model variability in the position of the BMC is significantly less than observations, as should be expected for such a mesoscale phenomenon, and there is limited meandering at the confluence region as the South Atlantic Current extends eastward across the South Atlantic.

\section{f. Interbasin exchange}

We assess the CCSM4 simulation of the Agulhas and Tasman leakages, defined as westward flow south of Africa and south of Tasmania, respectively, using numerical Lagrangian floats (e.g., Döös 1995; Donners and Drijfhout 2004; Doglioli et al. 2006; Richardson 2007; van Sebille et al. 2009a). In this study, float trajectories are calculated using the monthly 3D velocity fields of CCSM4. To calculate where floats need to be released, the meridional velocity at $32^{\circ} \mathrm{S}$ in the Agulhas Current (AC) and at $30^{\circ} \mathrm{S}$ in the East Australia Current (EAC) is interpolated to a regular grid with $100 \mathrm{~m}$ vertical and $0.25^{\circ}$ horizontal spacing. In the AC, this release grid extends from the surface to the ocean floor while in the EAC it is confined to the upper $2500 \mathrm{~m}$. For every month between 1980 and 2005, one float is released when the monthly mean interpolated velocity in the release grid cell is southward. Each of these floats is assigned a transport that is equal to the interpolated velocity in the grid cell times the gridcell area. In this way, the southward transport of the currents is sampled by the numerical floats. A total of $1.1 \times 10^{5}$ floats are released in the AC and $8.0 \times$ $10^{4}$ in the EAC. The floats are advected for $10 \mathrm{yr}$ using a Lagrangian code (Paris et al. 2011, unpublished manuscript) based on a fourth-order Runge-Kutta scheme. To account for some of the subgrid variability, an additional diffusion of $100 \mathrm{~m}^{2} \mathrm{~s}^{-1}$ is added.

\section{1) Agulhas leakage}

A time series of Agulhas leakage in each of the five CCSM4 20C ensemble members can be computed by determining, for each float that ends up in the Atlantic Ocean or has been west of $40^{\circ} \mathrm{W}$, the moment the float last crosses the GoodHope line (Fig. 14a). The GoodHope line is an XBT line following an Ocean Topography Experiment (TOPEX)-Poseidon-Jason-1 ground track (Ansorge et al. 2005; Swart et al. 2008) and is appropriately located for studying Agulhas leakage (van Sebille et al. 2010). The mean volume flux accomplished by Agulhas leakage, averaged over all ensemble members and the entire 1980-2005 period, is $43 \mathrm{~Sv}$. This is almost 3 times the 14-17 Sv estimates in eddy-permitting models (Doglioli et al. 2006; van Sebille et al. 2009a) or using surface drifters (Richardson 2007), and also larger than the $32 \mathrm{~Sv}$ reported by van Sebille et al. (2009b) in a numerical model at $1 / 2^{\circ}$ horizontal resolution. The AC transport in CCSM4, on the other hand, at $69 \mathrm{~Sv}$ is 


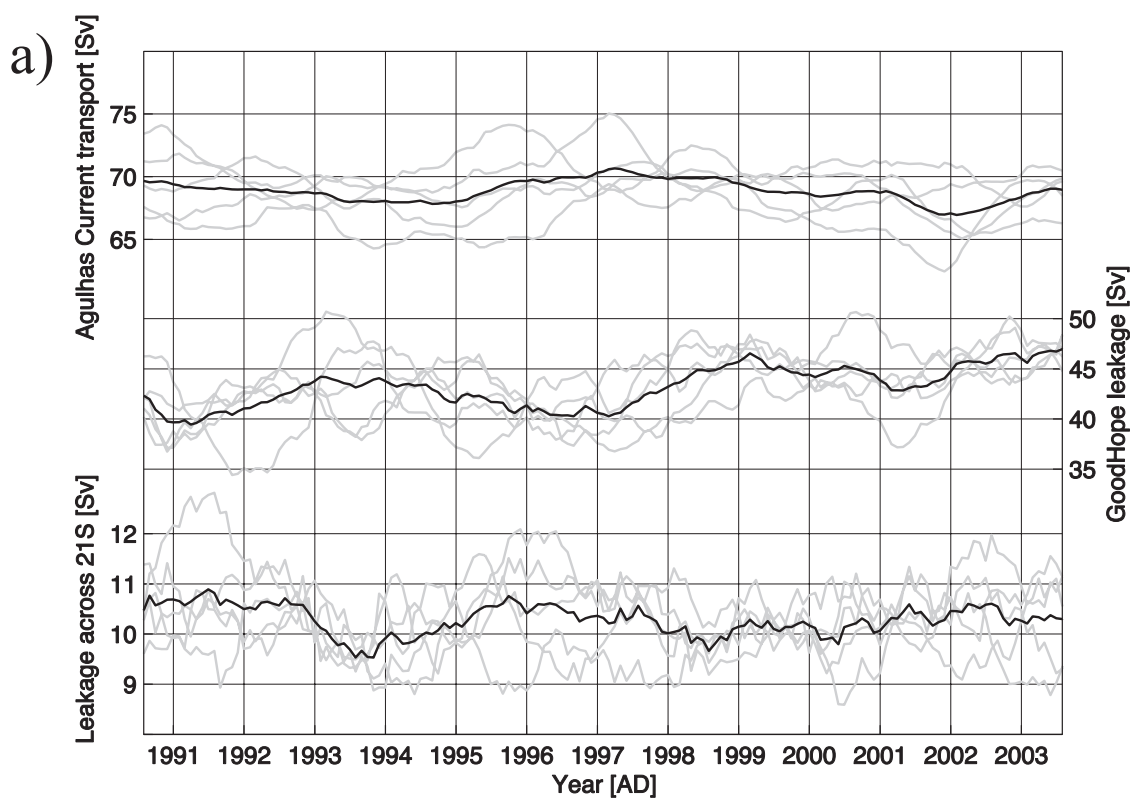

b)

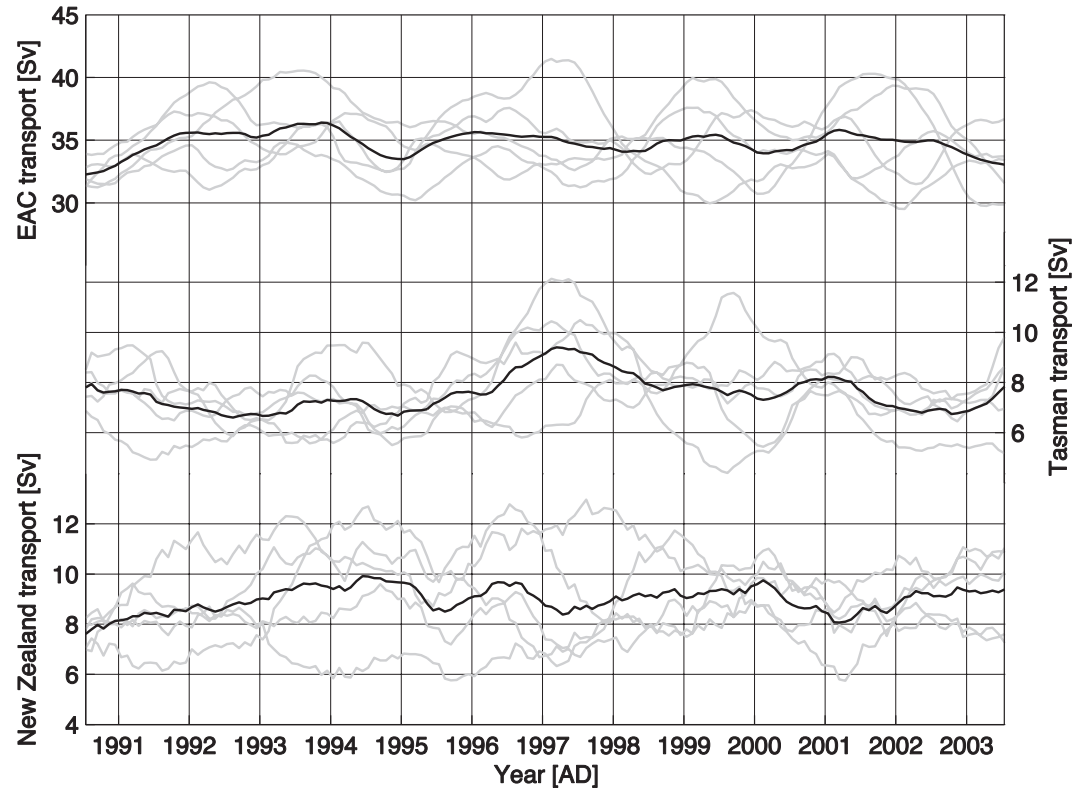

FIG. 14. (a) The time series of Agulhas Current transport at $32^{\circ} \mathrm{S}$ (upper lines), Agulhas leakage across the GoodHope line (middle lines), and Agulhas leakage northward across $21^{\circ} \mathrm{S}$ (lower lines) in the five CCSM4 20C ensemble members (gray lines individual members, black lines ensemble mean), computed from the numerical floats. (b) Time series of the transports of the EAC at $30^{\circ} \mathrm{S}$ (upper lines) and its bifurcations into the Tasman Outflow ( $146^{\circ} \mathrm{E}$, middle lines) and eastward Tasman Front transport north of New Zealand (175 $\mathrm{E}$, lower lines).

similar to the $70 \mathrm{~Sv}$ observed by Bryden et al. (2005) using a current meter array.

The effect of the supergyre circulation can be quantified by studying the time series of that part of Agulhas leakage that crosses $21^{\circ} \mathrm{S}$ in the Atlantic. This is the water that might eventually reach the tropical Atlantic and farther north. The magnitude of Agulhas leakage across $21^{\circ} \mathrm{S}$ in CCSM4 is $10 \pm 1 \mathrm{~Sv}$, which is similar to the amount of Agulhas leakage crossing the equator in a $14^{\circ}$ numerical model found by Donners and Drijfhout (2004) but larger than the $4 \mathrm{~Sv}$ found by Biastoch et al. (2009) crossing $6^{\circ} \mathrm{S}$ in a $1 / 10^{\circ}$ model.

All five ensemble members show a positive linear trend in Agulhas leakage across the GoodHope line over the 
period 1990-2005, with an average of $3.6 \pm 1.3 \mathrm{~Sv}$ decade $^{-1}$ Biastoch et al. (2009) also reported a positive trend in their eddy-resolving model, although smaller at $1.2 \mathrm{~Sv}$ decade $^{-1}$, where the authors argue that this trend is related to changing Southern Ocean winds in the recent decades (Beal et al. 2011). A more southerly latitude where the wind stress curl is zero would move the Antarctic subtropical front south and thus widen the gap for Indian Ocean water to flow into the Atlantic Ocean. Indeed, the mean latitude of zero wind stress curl over the Southern Ocean in CCSM4 moves southward in the period 19902005 at a rate of approximately $0.5^{\circ}$ decade $^{-1}$. At -0.1 $\pm 0.6 \mathrm{~Sv}$ decade $^{-1}$, there is no clear trend in Agulhas leakage across $21^{\circ} \mathrm{S}$, supporting the idea that most of the increase in Agulhas leakage across the GoodHope line feeds into the wind-driven supergyre (Speich et al. 2002).

\section{2) TASMAN LEAKAgE}

The EAC, the western boundary current of the South Pacific Ocean, bifurcates at approximately $35^{\circ} \mathrm{S}$ into two branches: the Tasman Front that meanders eastward across the Tasman Sea toward New Zealand, and the EAC extension that flows southward as a series of eddies and coastal current filaments to the southern tip of Tasmania (Suthers et al. 2011). The Tasman leakage, a residual component of the EAC extension, is identified as westward flow between Tasmania and the eastwardflowing ACC. Here we determine the transport of the EAC and bifurcation into the Tasman Front (New Zealand transport) and Tasman leakage in the CCSM4 model by seeding floats in the EAC at $30^{\circ} \mathrm{S}$ and tracking these until they pass through a control line as either westward flow at $146^{\circ} \mathrm{E}$ (Tasman leakage) or eastward flow at $175^{\circ} \mathrm{E}$ (north of $35^{\circ} \mathrm{S}$; New Zealand transport).

The CCSM4 simulates the transport of the EAC and its variability well (Fig. 14b). EAC geostrophic mean southward transport at $29^{\circ} \mathrm{S}$ is $25.2 \mathrm{~Sv}$ (Ridgway and Dunn 2003), which is somewhat lower than the 34.7 $\pm 2.5 \mathrm{~Sv}$ in the model. Rintoul and Sokolov (2001), from a series of repeat hydrographic sections, estimated the volume transport of the Tasman leakage (westward flow south of Tasmania) as $8 \pm 13 \mathrm{~Sv}$. The CCSM4 simulation has a 10 -yr mean westward flow of $7.6 \pm 1.4 \mathrm{~Sv}$ (Fig. 14b). However, CCSM4 eastward flow, north of New Zealand, associated with the Tasman front is relatively steady at approximately $9.0 \pm 1.6 \mathrm{~Sv}$. An observational estimate of the transport north of New Zealand is 11.2 Sv (Ridgway and Dunn 2003). The imbalance of approximately $18 \mathrm{~Sv}$ of southward flow in the EAC and exiting flow, either in the Tasman leakage or north of New Zealand, may be associated with recirculation of the EAC in the Tasman Sea by eddies that are shed from the EAC south of the bifurcation zone (Oke and Griffin 2011).

\section{Summary and conclusions}

In this paper we validate several aspects of the representation of the Southern Ocean in the CCSM4 through a comparison with observations. Specific areas of interest are the surface climatology and interannual variability (section 3), the representation of water masses and tracer distributions (section 4), and features of the large-scale circulation (section 5).

Consistent with observations, the surface climatology of the Southern Ocean in CCSM4 is controlled by the southern annular mode (SAM) and the remote influence of the El Niño-Southern Oscillation. The main characteristic of the $20 \mathrm{C}$ integrations is a significant cold bias with respect to observations in the Antarctic surface waters, but also a significant warming trend that is stronger than in observations. In addition, we found a significant strengthening of the westerlies, associated with a shift to more positive values of the SAM, in agreement with observations. However, the warming trend in the Southern Ocean is clearly forced by atmospheric warming and is in places counteracted by the strengthening of the SAM.

The key climate water masses of the Southern OceanAntarctic Bottom Water (AABW), Subantarctic Mode Water (SAMW), and Antarctic Intermediate Water (AAIW) - are not well simulated in the CCSM4 model. Weddell Sea AABW is not found in the model and Ross Sea AABW is too salty. The poor simulation of AABW results in an inaccurate representation of the abyssal density and an unrealistically large vertical density gradient below $2000 \mathrm{~m}$ in the Indian and Pacific Oceans north of $40^{\circ} \mathrm{S}$. In contrast, the abyssal Atlantic Ocean has a weaker-than-observed density gradient as no AABW is found north of $40^{\circ} \mathrm{S}$. Danabasoglu et al. (2012) note that the model AABW salinity and density biases of the 20C model run largely reflect the bias that exists at the end of the control run. This suggests that although sea ice production and changing wind forcing in the twentieth century may influence the properties of $\mathrm{AABW}$, the large biases in $\mathrm{AABW}$ are a result of systematic errors in the coupled ocean-ice-atmosphere system and perhaps implementation of the overflow parameterization in the Southern Ocean.

Differences between the model and observed temperature, salinity, potential vorticity winter mixed layer depth, and CFC-11 properties shed light on the formation and ventilation of SAMW and AAIW in CCSM4. Recent studies have suggested that eddies, turbulent mixing, ocean stratification, and mesoscale processes influence the formation and properties of SAMW and 
AAIW (Sallée et al. 2008; Sloyan et al. 2010; HerraizBorreguero and Rintoul 2010; Hartin et al. 2011). A more thorough comparison of the CCSM4 simulation of SAMW and AAIW is needed to fully understand the causes of the model deficiencies. Higher model CFC11 concentrations, south of the Antarctic Circumpolar Current (ACC) in the Indian and Pacific sectors between the surface and $2000 \mathrm{~m}$, may be due to deficiencies in the representation of Southern Ocean overturning circulation, particularly the upwelling of CFC-free Upper Circumpolar Deep Water (Sloyan and Rintoul 2001b). This suggests that the model may underestimate the sequestration of heat, carbon, and other properties to the interior ocean.

The transport of the ACC is reduced in CCSM4 compared to CCSM3, but it is still too high relative to observations. Apparent insensitivity of the ACC transport to late twentieth-century increases in zonal wind stress suggests that improved formulations of the isopycnal tracer transport may have reduced the dynamical response of the ACC to wind stress variability. The model represents the main frontal zones associated with the ACC jets, and their location is surprisingly well simulated.

The Brazil-Malvinas Confluence is a region where the low spatial resolution introduces biases in the model. Although the Brazil Current in the South Atlantic is about twice as strong as observed, the confluence with the northward-flowing Malvinas Current is biased toward the south and displays much less variability than in observations. The stronger circulation introduces warm biases to the north of the subtropical convergence and the South Atlantic Current and cold biases to the south, enhancing the meridional SST gradient.

The CCSM4 model does simulate the Southern Hemisphere interbasin exchange to a reasonable degree. The main bias is the representation of Agulhas leakage, which is almost three times as high as in observations. The current generation of climate models does not resolve ocean mesoscale processes and require a relatively high viscosity to represent the effects of eddy stirring. Consequently, the Agulhas Current (as well as other boundary currents) is too viscous and lacks the inertia necessary for retroflection and ring shedding. Instead, a substantial fraction of the transport is carried directly into the South Atlantic in a viscous boundary layer (e.g., de Ruijter 1982; Dijkstra and de Ruijter 2001), overestimating the volume of water exchanged between the Indian and Atlantic Oceans. Nonetheless, the amount of Agulhas leakage that reaches the tropical Atlantic is reasonably close to what studies with higher-resolution models have found. In addition, the variability and trend of Agulhas leakage are reasonably well captured. The Tasman leakage is also well simulated in CCSM4, although the bifurcations of the East Australia Current (EAC) into the Tasman front and EAC extension may be influenced by biases in the latitudinal position of the South Pacific wind stress curl. Further analysis of the model is required to fully understand the impact of largescale wind forcing and variability to the return pathways of the global overturning circulation.

Many of the key Southern Ocean processes that result in water mass formation and interbasin exchanges depend on mesoscale features that are not explicitly resolved in the model. The Southern Ocean may therefore be particularly susceptible to the flaws and virtues of subgrid-scale parameterizations of the mesoscale processes, including eddies, ocean interior mixing, mixed layer processes, and overflow entrainments. The analyses presented in this paper show that these parameterizations may indeed lead to significant biases in the representation of the Southern Ocean and its climate. Nonetheless, the CCSM4 model provides a powerful tool to understand and predict the evolution of the earth's climate system. This study has identified aspects of the model that warrant further analysis that will result in a more comprehensive understanding of oceanatmosphere-ice dynamics and interactions that control the earth's climate and variability.

Acknowledgments. The CESM project is supported by the National Science Foundation (NSF) and the Office of Science of the U.S. Department of Energy (DOE-OoS). This research was supported by the Regional and Global Climate Prediction Program of the DOE-OoS (WW, MEM, NJ, and MWH); NSF-OCE Award 0928473 (WW); the Australian Climate Change Science Program, funded jointly by the Department of Climate Change and Energy Efficiency and CSIRO (BMS); CNPq-MCT/INCT and FAPESP (IW); NSF (EvS, CAH); and NSF Polar Programs Grant 0908675 (LL). The National Center for Atmospheric Research (NCAR) is sponsored by NSF. Computing resources were provided by the Climate Simulation Laboratory at NCAR's Computational and Information Systems Laboratory (CISL), sponsored by NSF and other agencies. The authors thank Gary Strand and the staff of the Earth System Grid for processing the CCSM4 data and making it available through http:// www.earthsystemgrid.org. Thanks to Martin Visbeck (IFM-GEOMAR) and Gareth Marshall (BAS) for providing their SAM indices. ERA-40 data were provided by the European Centre for Medium-Range Weather Forecasts (ECMWF). NOAA ERSSTv3b data were provided by the NOAA/OAR/ESRL Physical Sciences Division in Boulder, CO, from their website at http:// www.esrl.noaa.gov/psd/. The Connectivity Modeling System (CMS) for the Lagrangian advection of particles most 
current development was funded by the NSF-OCE RAPID Award 1048697 to C. B. Paris. The authors thank Peter Gent and two anonymous reviewers for their valuable comments.

\section{REFERENCES}

Ammann, C. M., G. A. Meehl, W. M. Washington, and C. S. Zender, 2003: A monthly and latitudinally varying volcanic forcing dataset in simulations of 20th century climate. Geophys. Res. Lett., 30, 1657, doi:10.1029/2003GL016875.

Ansorge, I. J., S. Speich, J. R. E. Lutjeharms, G. J. Goni, C. J. Rautenbach, P. W. Froneman, M. Rouault, and S. L. Garzoli, 2005: Monitoring the oceanic flow between Africa and Antarctica: Report of the first GoodHope cruise. S. Afr. J. Sci., 101, 29-35.

Beal, L. M., and Coauthors, 2011: On the role of the Agulhas system in global climate. Nature, 472, 429-436.

Berger, W. H., and G. Wefer, 1996: Expeditions into the past: Paleoceanographic studies in the South Atlantic. The South Atlantic: Present and Past Circulation, G. Wefer et al., Eds., SpringerVerlag, 353-410.

Biastoch, A., C. W. Böning, and J. R. E. Lutjeharms, 2008: Agulhas leakage dynamics affects decadal variability in Atlantic overturning circulation. Nature, 456, 489-492.

,,-- F. U. Schwarzkopf, and J. R. E. Lutjeharms, 2009: Increase in Agulhas leakage due to poleward shift of Southern Hemisphere westerlies. Nature, 462, 495-499.

Briegleb, B., G. Danabasoglu, and W. Large, 2010: An overflow parameterization for the ocean component of the Community Climate System Model. National Center for Atmospheric Research Tech. Rep. NCAR/TN-481+STR, 72 pp.

Bromwich, D., and R. Fogt, 2004: Strong trends in the skill of the ERA-40 and NCEP-NCAR reanalyses in the high and midlatitudes of the Southern Hemisphere, 1958-2001. J. Climate, 17, 4603-4619.

Bryden, H. L., L. M. Beal, and L. M. Duncan, 2005: Structure and transport of the Agulhas Current and its temporal variability. J. Oceanogr., 61, 479-492.

Byrne, D. A., A. L. Gordon, and W. F. Haxby, 1995: Agulhas eddies: A synoptic view using Geosat ERM data. J. Phys. Oceanogr., 25, 902-917.

Carton, J., and B. Giese, 2008: A reanalysis of ocean climate using Simple Ocean Data Assimilation (SODA). Mon. Wea. Rev., 136, 2999-3017.

Cunningham, S. A., S. G. Alderson, B. A. King, and M. A. Brandon, 2003: Transport and variability of the Antarctic Circumpolar Current in Drake Passage. J. Geophys. Res., 108, 8084, doi:10.1029/2001JC001147.

Danabasoglu, G., W. G. Large, and B. P. Briegleb, 2010: Climate impacts of parameterized Nordic Sea overflows. J. Geophys. Res., 115, C11005, doi:10.1029/2010JC006243.

_, S. C. Bates, B. P. Briegleb, S. R. Jayne, W. Jochum, M. G. Large, S. Peacock, and S. G. Yeager, 2012: The CCSM4 ocean component. J. Climate, 25, 1361-1389.

de Ruijter, W., 1982: Asymptotic analysis of the Agulhas and Brazil current systems. J. Phys. Oceanogr., 12, 361-373.

—, A. Biastoch, S. S. Drijfhout, J. R. E. Lutjeharms, R. P. Matano, T. Pichevin, P. J. van Leeuwen, and W. Weijer, 1999: Indian-Atlantic interocean exchange: Dynamics, estimation and impact. J. Geophys. Res., 104, 20 885-20 910.

Dijkstra, H. A., and W. P. M. de Ruijter, 2001: Barotropic instabilities of the Agulhas Current system and their relation to ring formation. J. Mar. Res., 59, 517-533.
Doglioli, A. M., M. Veneziani, B. Blanke, S. Speich, and A. Griffa, 2006: A Lagrangian analysis of the Indian-Atlantic interocean exchange in a regional model. Geophys. Res. Lett., 33, L14611, doi:10.1029/2006GL026498.

Donners, J., and S. S. Drijfhout, 2004: The Lagrangian view of South Atlantic interocean exchange in a global ocean model compared with inverse model results. J. Phys. Oceanogr., 34, 1019-1035.

Döös, K., 1995: Interocean exchange of water masses. J. Geophys. Res., 100, 13 499-13 514

Fahrbach, E., S. Harms, G. Rohardt, M. Schroder, and R. Woodgate, 2001: Flow of bottom water in the northwestern Weddell Sea. J. Geophys. Res., 106, 2761-2778.

Fine, R. A., 2011: Observations of CFCs and SF6 as ocean tracers. Ann. Rev. Mar. Sci., 3, 173-195. W. M. Smethie Jr., J. L. Bullister, M. Rhein, D.-H. Min, M. J. Warner, A. Poisson, and R. F. Weiss, 2008: Decadal ventilation and mixing of Indian Ocean waters. Deep-Sea Res. I, 55, 20-37, doi:10.1016/j.dsr.2007.10.002.

Fogt, R. L., and D. H. Bromwich, 2006: Decadal variability of the ENSO teleconnection to the high-latitude South Pacific governed by coupling with the southern annular mode. J. Climate, 19, 979-997.

, — , and K. M. Hines, 2011: Understanding the SAM influence on the South Pacific ENSO teleconnection. Climate Dyn., 36, 1555-1576.

Foldvik, A., and Coauthors, 2004: Ice shelf water overflow and bottom water formation in the southern Weddell Sea. J. Geophys. Res., 109, C02015, doi:10.1029/2003JC002008.

Fox-Kemper, B., and Coauthors, 2011: Parameterization of mixed layer eddies. III: Implementation and impact in global ocean climate simulations. Ocean Modell., 39, 61-78.

Franzese, A. M., S. R. Hemming, S. L. Goldstein, and R. F. Anderson, 2006: Reduced Agulhas leakage during the last glacial maximum inferred from an integrated provenance and flux study. Earth Planet. Sci. Lett., 250, 72-88.

Fukamachi, Y., S. R. Rintoul, J. A. Church, S. Aoki, S. Sokolov, M. A. Rosenberg, and M. Wakatsuchi, 2010: Strong export of Antarctic Bottom Water east of the Kerguelen plateau. Nat. Geosci., 3, 327-331.

Garzoli, S. L., and Z. Garraffo, 1989: Transports, frontal motions and eddies at the Brazil-Malvinas currents confluence. DeepSea Res., 36A, 681-703.

Gent, P. R., and G. Danabasoglu, 2011: Response to increasing Southern Hemisphere winds in CCSM4. J. Climate, 24, 4992-4998. , and Coauthors, 2011: The Community Climate System Model version 4. J. Climate, 24, 4973-4991.

Ghil, M., and K. Mo, 1991: Intraseasonal oscillations in the global atmosphere. Part II: Southern Hemisphere. J. Atmos. Sci., 48, 780-790

Gong, D., and S. Wang, 1999: Definition of Antarctic oscillation index. Geophys. Res. Lett., 26, 459-462.

Gordon, A. L., 1986: Interocean exchange of thermohaline water. J. Geophys. Res., 91, 5037-5046.

—, R. F. Weiss, W. M. Smethie Jr., and M. J. Warner, 1992: Thermocline and intermediate water communication between the South Atlantic and Indian Oceans. J. Geophys. Res., 97, $7223-7240$

, M. Visbeck, and B. Huber, 2001: Export of Weddell Sea deep and bottom water. J. Geophys. Res., 106, 9005-9017.

, E. Zambianchi, A. Orsi, M. Visbeck, C. F. Giulivi, T. Whitworth III, and G. Spezie, 2004: Energetic plumes over the western Ross Sea continental slope. Geophys. Res. Lett., 31, L21302, doi:10.1029/2004GL020785. 
Hall, A., and M. Visbeck, 2002: Synchronous variability in the Southern Hemisphere atmosphere, sea ice, and ocean resulting from the annular mode. J. Climate, 15, 3043-3057.

Hallberg, R., and A. Gnanadesikan, 2006: The role of eddies in determining the structure and response of the wind-driven Southern Hemisphere overturning: Results from the Modeling Eddies in the Southern Ocean (MESO) project. J. Phys. Oceanogr., 36, 2232-2252.

Hartin, C., R. Fine, B. M. Sloyan, L. T. Talley, T. K. Chereskin, and J. Happell, 2011: Formation rates of Subantarctic Mode Water and Antarctic Intermediate Water within the South Pacific. Deep-Sea Res., 58, 524-534.

Herraiz-Borreguero, L., and S. R. Rintoul, 2010: Subantarctic Mode Water variability influenced by mesoscale eddies south of Tasmania. J. Geophys. Res., 115, C04004, doi:10.1029/ 2008JC005146.

Johnson, G. C., 2008: Quantifying Antarctic Bottom Water and North Atlantic Deep Water volumes. J. Geophys. Res., 113, C05027, doi:10.1029/2007JC004477.

Jullion, L., K. J. Heywood, A. C. Naveira Garabato, and D. P. Stevens, 2010: Circulation and water mass modification in the BrazilMalvinas Confluence. J. Phys. Oceanogr., 40, 845-864.

Karoly, D. J., 1989: Southern hemisphere circulation features associated with El Niño-Southern Oscillation events. J. Climate, 2, 1239-1252.

Knorr, G., and G. Lohmann, 2003: Southern Ocean origin for the resumption of Atlantic thermohaline circulation during deglaciation. Nature, 424, 532-536.

Kwok, R., and J. C. Comiso, 2002: Southern Ocean climate and sea ice anomalies associated with the southern oscillation. J. Climate, 15, 487-501.

Landrum, L., M. M. Holland, D. P. Schneider, and E. C. Hunke, 2012: Antarctic sea ice climatology, variability, and late twentieth-century change in CCSM4. J. Climate, in press.

Lee, S.-K., W. Park, E. van Sebille, M. Baringer, C. Wang, D. B. Enfield, S. Yeager, and B. Kirtman, 2011: What caused the significant increase in Atlantic Ocean heat content since the mid-20th century? Geophys. Res. Lett., 38, L17607, doi:10.1029/ 2011GL048856.

Legg, S., and Coauthors, 2009: Improving oceanic overflow representation in climate models: The gravity current entrainment climate process team. Bull. Amer. Meteor. Soc., 90, 657-670.

l'Heureux, M. L., and D. W. J. Thompson, 2006: Observed relationships between the El Niño-Southern Oscillation and the extratropical zonal-mean circulation. J. Climate, 19, 276-287.

Maltrud, M. E., R. D. Smith, A. J. Semtner, and R. C. Malone, 1998: Gobal eddy-resolving ocean simulations driven by 1985 1995 atmospheric winds. J. Geophys. Res., 103, 30 825-30 853.

Marsh, R., W. Hazeleger, A. Yool, and E. J. Rohling, 2007: Stability of the thermohaline circulation under millennial $\mathrm{CO}_{2}$ forcing and two alternative controls on Atlantic salinity. Geophys. Res. Lett., 34, L03605, doi:10.1029/2006GL027815.

Marshall, G. J., 2003: Trends in the southern annular mode from observations and reanalyses. J. Climate, 16, 4134-4143.

McCartney, M. S., and K. A. Donohue, 2007: A deep cyclonic gyre in the Australian-Antarctic Basin. Prog. Oceanogr., 75, 675750 .

Meehl, G. A., W. M. Washington, C. M. Ammann, J. M. Arblaster, T. M. L. Wigley, and C. Tebaldi, 2004: Combinations of natural and anthropogenic forcings in twentieth-century climate. J. Climate, 17, 3721-3727.

Meredith, M. P., and Coauthors, 2011: Sustained monitoring of the Southern Ocean at Drake Passage: Past achievements and future priorities. Rev. Geophys., 49, RG4005, doi:10.1029/ 2010RG000348.

Mo, K. C., 2000: Relationships between low-frequency variability in the Southern Hemisphere and sea surface temperature anomalies. J. Climate, 13, 3599-3610.

—_, and M. Ghil, 1987: Statistics and dynamics of persistent anomalies. J. Atmos. Sci., 44, 877-901.

, and R. W. Higgins, 1998: The Pacific-South American modes and tropical convection during the Southern Hemisphere winter. Mon. Wea. Rev., 126, 1581-1596.

Oke, P. R., and D. A. Griffin, 2011: The cold-core eddy and strong upwelling off the coast of New South Wales in early 2007. Deep-Sea Res. II, 58, 574-591.

Olson, D. B., G. P. Podesta, R. H. Evans, and O. B. Brown, 1988: Temporal variations in the separation of Brazil and Malvinas Currents. Deep-Sea Res., 35A, 1970-1990.

Orsi, A. H., T. Whitworth III, and W. D. Nowlin Jr., 1995: On the meridional extent and fronts of the Antarctic circumpolar current. Deep-Sea Res. I, 42, 641-673.

— G. G. Johnson, and J. L. Bullister, 1999: Circulation, mixing, and production of Antarctic Bottom Water. Prog. Oceanogr., 43, 55-109, doi:10.1016/S0079-6611(99)00004-X.

Peeters, F., R. Acheson, G. Brummer, W. De Ruijter, R. Schneider, G. Ganssen, E. Ufkes, and D. Kroon, 2004: Vigorous exchange between the Indian and Atlantic oceans at the end of the past five glacial periods. Nature, 430, 661-665.

Raphael, M. N., and M. M. Holland, 2006: Twentieth century simulation of the Southern Hemisphere climate in coupled models. Part I: Large scale circulation variability. Climate Dyn., 26, 217228.

Renwick, J. A., 1998: ENSO-related variability in the frequency of South Pacific blocking. Mon. Wea. Rev., 126, 3117-3123.

__ and M. J. Revell, 1999: Blocking over the South Pacific and Rossby wave propagation. Mon. Wea. Rev., 127, 2233-2247.

Richardson, P. L., 2007: Agulhas leakage into the Atlantic estimated with subsurface floats and surface drifters. Deep-Sea Res. I, 54, 1361-1389.

Ridgway, K. R., and J. R. Dunn, 2003: Mesoscale structure of the mean East Australian Current System and its relationship with topography. Prog. Oceanogr., 56, 189-222.

$\longrightarrow,-$, and J. L. Wilkin, 2002: Ocean interpolation by fourdimensional weighted least squares-Application to the waters around Australasia. J. Atmos. Oceanic Technol., 19, 1357-1375.

Rintoul, S. R., and S. Sokolov, 2001: Baroclinic transport variability of the Antarctic Circumpolar Current south of Australia (WOCE repeat section SR3). J. Geophys. Res., 106, 28152832.

— C. Hughes, and D. Olbers, 2001: The Antarctic Circumpolar Current System. Ocean Circulation and Climate, J. C. G. Siedler and J. Gould, Eds., Academic Press, 271-302.

Sabine, C. L., and Coauthors, 2004: The oceanic sink for anthropogenic $\mathrm{CO}_{2}$. Science, 305, 367-371.

Sallée, J.-B., R. Morrow, and K. Speer, 2008: Eddy heat diffusion and Subantarctic Mode Water formation. Geophys. Res. Lett., 35, L05607, doi:10.1029/2007GL032827.

Sarmiento, J., N. Gruber, M. A. Brzezinski, and J. P. Dunne, 2004: High-latitude controls of thermocline nutrients and low latitude biological productivity. Nature, 427, 56-60.

Scambos, T. A., T. M. Haran, M. A. Fahnestock, T. H. Painter, and J. Bohlander, 2007: MODIS-based Mosaic of Antarctica (MOA) data sets: Continent-wide surface morphology and snow grain size. Remote Sens. Environ., 111, 242-257. 
Schouten, M. W., W. P. M. de Ruijter, P. J. van Leeuwen, and J. R. E. Lutjeharms, 2000: Translation, decay and splitting of Agulhas rings in the southeastern Atlantic Ocean. J. Geophys. Res., 105, 21 913-21 925.

Sen Gupta, A., and M. H. England, 2006: Coupled ocean-atmosphereice response to variations in the southern annular mode. J. Climate, 19, 4457-4486.

Sloyan, B. M., and S. R. Rintoul, 2001a: Circulation, renewal, and modification of Antarctic mode and intermediate water. J. Phys. Oceanogr., 31, 1005-1030.

— , and _ 2001b: The Southern Ocean limb of the global deep overturning circulation. J. Phys. Oceanogr., 31, 143-173.

— Mode and Antarctic Intermediate waters in climate models J. Climate, 20, 5061-5080.

- , L. T. Talley, T. K. Chereskin, R. Fine, and J. Holte, 2010: Antarctic Intermediate Water and Subantarctic Mode Water formation in the southeast Pacific: The role of turbulent mixing. J. Phys. Oceanogr., 40, 1558-1574.

Smith, R., and Coauthors, 2010: The Parallel Ocean Program (POP) reference manual. Los Alamos National Laboratory Tech. Rep., 141 pp.

Smith, T. M., R. W. Reynolds, T. C. Peterson, and J. Lawrimore, 2008: Improvements to NOAA's historical merged landocean surface temperature analysis (1880-2006). J. Climate, 21, 2283-2296.

Sokolov, S., and S. R. Rintoul, 2009: Circumpolar structure and distribution of the Antarctic Circumpolar Current fronts: 1. Mean circumpolar paths. J. Geophys. Res., 114, C11018, doi:10.1029/2008JC005108.

Speich, S., B. Blanke, P. de Vries, S. S. Drijfhout, K. Döös, A. Ganachaud, and R. Marsh, 2002: Tasman leakage: A new route in the global ocean conveyor belt. Geophys. Res. Lett., 29, 1416, doi:10.1029/2001GL014586.

Stramma, L., and R. G. Peterson, 1990: The South Atlantic current. J. Phys. Oceanogr., 20, 846-859.

Suthers, I., and Coauthors, 2011: The strengthening East Australian Current, its eddies and biological effects-An introduction and overview. Deep-Sea Res. II, 58, 538-546.

Swart, S., S. Speich, I. J. Ansorge, G. J. Goni, S. Gladyshev, and J. R. E. Lutjeharms, 2008: Transport and variability of the Antarctic Circumpolar Current south of Africa. J. Geophys. Res., 113, C09014, doi:10.1029/2007JC004223.

Tchernia, P., 1980: Descriptive Physical Oceanography. Pergamon Press, $253 \mathrm{pp}$.
Thomas, D. N., and G. Dieckmann, 2003: Sea Ice: An Introduction to Its Physics, Chemistry, Biology, and Geology. WileyBlackwell, $416 \mathrm{pp}$.

Thompson, D. W. J., and J. M. Wallace, 2000: Annular modes in the extratropical circulation. Part I: Month-to-month variability. J. Climate, 13, 1000-1016.

Tomczak, M., and J. S. Godfrey, 2003: Regional Oceanography: An Introduction. Daya Publishing House, $380 \mathrm{pp}$.

Trenberth, K. E., 1997: The definition of El Niño. Bull. Amer. Meteor. Soc., 78, 2771-2777.

Turner, J., 2004: The El Niño-Southern Oscillation and Antarctica. Int. J. Climatol., 24, 1-31.

Uppala, S. M., and Coauthors, 2005: The ERA-40 Re-Analysis. Quart. J. Roy. Meteor. Soc., 131, 2961-3012.

van Sebille, E., and P. J. van Leeuwen, 2007: Fast northward energy transfer in the Atlantic due to Agulhas rings. J. Phys. Oceanogr., 37, 2305-2315.

_ C. N. Barron, A. Biastoch, P. J. van Leeuwen, F. C. Vossepoel, and W. P. M. de Ruijter, 2009a: Relating Agulhas leakage to the Agulhas Current retroflection location. Ocean Sci., 5, 511-521.

, P. J. van Leeuwen, A. Biastoch, C. N. Barron, and W. P. M. de Ruijter, 2009b: Lagrangian validation of numerical drifter trajectories using drifting buoys: Application to the Agulhas region. Ocean Modell., 29, 269-276.

,,--- , and W. P. M. de Ruijter, 2010: On the fast decay of Agulhas rings. J. Geophys. Res., 115, C03010, doi:10.1029/ 2009JC005585.

Visbeck, M., 2009: A station-based southern annular mode index from 1884 to 2005. J. Climate, 22, 940-950.

Wainer, I., P. Gent, and G. Goni, 2000: Annual cycle of the BrazilMalvinas confluence region in the National Center for Atmospheric Research Climate System Model. J. Geophys. Res., 105, 26 167-26 177

Weijer, W., W. P. M. de Ruijter, H. A. Dijkstra, and P. J. van Leeuwen, 1999: Impact of interbasin exchange on the Atlantic overturning circulation. J. Phys. Oceanogr., 29, 2266-2284.

, — - A. Sterl, and S. S. Drijfhout, 2002: Response of the Atlantic overturning circulation to South Atlantic sources of buoyancy. Global Planet. Change, 34, 293-311.

Williams, G. D., S. Aoki, S. S. Jacobs, S. R. Rintoul, T. Tamura, and N. L. Bindoff, 2010: Antarctic Bottom Water from the Adélie and George V Land coast, east Antarctica $\left(140-149^{\circ} \mathrm{E}\right)$. J. Geophys. Res., 115, C04027, doi:10.1029/2009JC005812.

Wunsch, C., 1998: The work done by the wind on the oceanic general circulation. J. Phys. Oceanogr., 28, 2332-2340. 